\title{
Succinate Dehydrogenase and Ribonucleic Acid Networks in Cancer and Other Diseases
}

\author{
Cerena Moreno ${ }^{+} \mathbb{D}$, Ruben Mercado Santos ${ }^{+} \mathbb{D}$, Robert Burns ${ }^{\dagger}$ and Wen Cai Zhang ${ }^{*}$ (D) \\ Department of Cancer Division, Burnett School of Biomedical Sciences, College of Medicine, University of \\ Central Florida, 6900 Lake Nona Blvd, Orlando, FL 32827, USA; cerenamoreno@Knights.ucf.edu (C.M.); \\ ruben.mercado30@Knights.ucf.edu (R.M.S.); robertburns@knights.ucf.edu (R.B.) \\ * Correspondence: wencai.zhang@ucf.edu; Tel.: +14-(07)-2667178 \\ † These authors contributed equally to this work.
}

Received: 25 September 2020; Accepted: 30 October 2020; Published: 3 November 2020

Simple Summary: Although the dysfunction of the succinate dehydrogenase complex in mitochondria leads to cancer and other diseases due to aberrant metabolic reactions and signaling pathways, it is not well known how the succinate dehydrogenase complex is regulated. Our review highlights that non-coding ribonucleic acids (RNAs), RNA editing enzymes, and RNA modifying enzymes regulate expressions and functions of the succinate dehydrogenase complex. This research will provide new strategies for treating succinate dehydrogenase-relevant diseases in a clinic.

Abstract: Succinate dehydrogenase (SDH) complex connects both the tricarboxylic acid (TCA) cycle and the electron transport chain (ETC) in the mitochondria. However, SDH mutation or dysfunction-induced succinate accumulation results in multiple cancers and non-cancer diseases. The mechanistic studies show that succinate activates hypoxia response and other signal pathways via binding to 2-oxoglutarate-dependent oxygenases and succinate receptors. Recently, the increasing knowledge of ribonucleic acid (RNA) networks, including non-coding RNAs, RNA editors, and RNA modifiers has expanded our understanding of the interplay between SDH and RNA networks in cancer and other diseases. Here, we summarize recent discoveries in the RNA networks and their connections to SDH. Additionally, we discuss current therapeutics targeting SDH in both pre-clinical and clinical trials. Thus, we propose a new model of SDH-RNA network interaction and bring promising RNA therapeutics against SDH-relevant cancer and other diseases.

Keywords: succinate dehydrogenase; cancer; disease; tricarboxylic acid cycle; electron transport chain; metabolism; reactive oxygen species; non-coding RNA; RNA-editing; RNA-modification

\section{Introduction}

Succinate dehydrogenase (SDH) is a mitochondrial enzyme present in supporting metabolic function through the tricarboxylic acid cycle (TCA cycle) and the electron transport chain (ETC). The yme works by catalyzing succinate to fumarate by oxidation in the TCA cycle, then ubiquinone is reduced to ubiquinol in the ETC [1]. As a part of the TCA cycle, SDH gains electrons and transfers them through the four subunits (SDHA, SDHB, SDHC, SDHD) and continues this electron transfer through the ETC as complex II. The electrons from $\mathrm{FADH}_{2}$ and reduced ubiquinone are transferred to complex III to continue the production of adenosine triphosphate. This produces the energy for the cell. With the regulation of this enzyme through its various complexes, the cells are able to perform cellular respiration, hypoxic response, and other cellular activities such as gene expression. However, altered SDH activity could give rise to disease and cancer development due to reduced electron flow, increased oxygen toxicity, and accumulated succinate. Due to the various subunits within the SDH complex, the difference 
in functionality can be responsible for these metabolic changes. In some human cancer cells, SDH demonstrates tumor-suppressive properties by inactivating hypoxia-inducible factor $1 \alpha(\mathrm{HIF}-1 \alpha)$ via reduced succinate [2]. Additionally, the subunits of SDH can interact with ribonucleic acid (RNA) regulatory networks including non-coding RNAs, RNA-editing enzymes, RNA-modifying enzymes, transcription factors, and small molecules. A consequence of RNA modifications and deregulation of non-coding RNAs is the ability to act as tumor suppressors or oncogenes and alter gene expression, dysregulate cell signaling pathways, and alter cell metabolism [3,4]. Among them, non-coding RNAs can target SDH and contribute to complex dysfunction [5,6]. Additionally, SDH can be influenced by non-coding RNAs that are regulated by RNA-editing [7] and RNA-modifying enzymes [8] as well as transcription factors that have been found to contribute to various cancers. To combat the effects induced by SDH mutations or metabolic dysfunctions, multiple molecules including SDH inhibitors and activators are evaluated in current pre-clinical models and clinical trials. Here, we summarize the SDH-relevant physiological and pathological mechanisms as well as diseases including cancer. Additionally, we discuss innovative ways that RNA networks influence SDH state and promising strategies for targeting the SDH complex.

\section{Succinate Dehydrogenase-Associated Genes and Protein Structures}

\subsection{SDH Complex-Associated Genes}

The SDH complex is composed of four subunits that are encoded through nuclear genes: SDHA-D in mammals, SDH1-4 in yeast, and SDH1-8 in plants (Figure 1). Each subunit of the complex functions through assembly genes including SDHAF1, SDHAF2, SDHAF3, and SDHAF4 or SDH5, SDH6, SDH7, and $S D H 8$ in yeast. SDHAF2 is an important assembly factor of flavination of SDHA, needed for the SDH complex to be functional. SDHAF2 works in conjunction with dicarboxylates of the TCA cycle by stabilizing the active site of SDHA [9]. SDHAF1 provides iron-sulfur (Fe-S) clusters for SDHB by first binding then recruiting the iron-sulfur cluster co-chaperone protein $\mathrm{HscB}$ (HSC20) [10]. SDHAP1, $S D H A P 2$, and SDHAP3 are pseudogenes that are a part of the SDHA complex (refer to GeneCards). Recently, it was found that IncRNA SDHAP1 upregulated the expression of EIF4G2 by reducing miR-4465 levels in ovarian cancer cells [11]. This suggests that the pseudogenes may regulate gene expressions through sponging microRNAs [12]. Further study of regulation by SDHAP1-3 in the $\mathrm{SDH}$ complex could be beneficial for understanding the functions of the SDH complex that is beyond metabolic reactions.

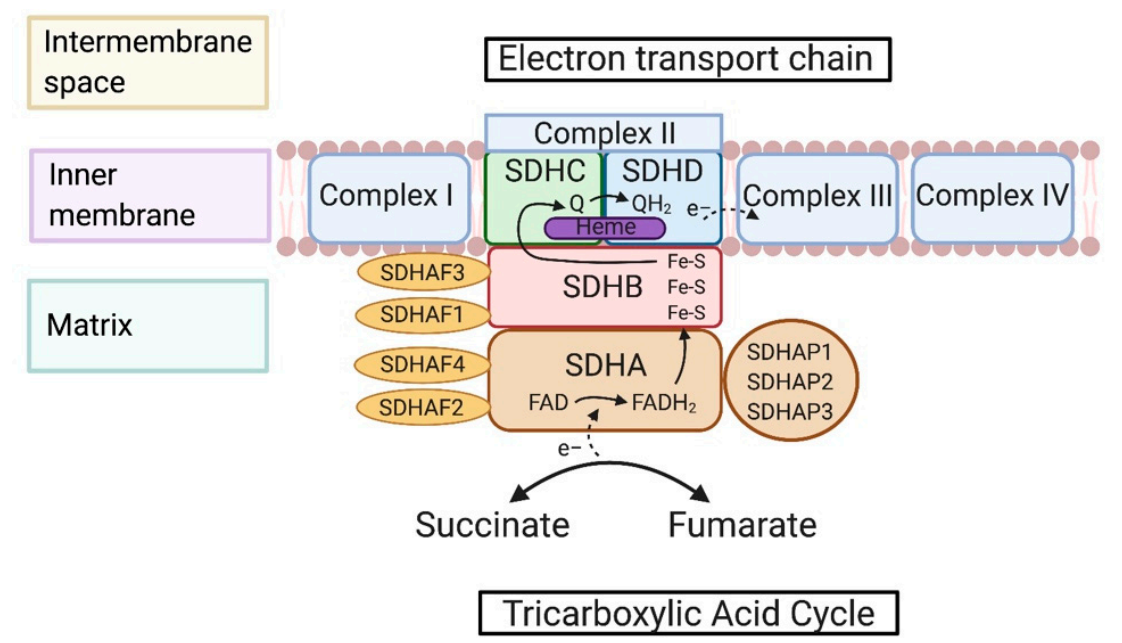

Figure 1. Structure, maturation, and assembly of succinate dehydrogenase (SDH) complex. The SDH complex, or mitochondrial complex II, sits within the inner mitochondrial membrane and is included in 
both the tricarboxylic acid cycle (TCA) and the electron transport chain (ETC). Succinate is an enzyme that is a part of the TCA cycle and is oxidized to fumarate through SDH; this is also present in the reverse reaction. From the oxidization, two electrons are transferred to subunit A to protonate FAD to $\mathrm{FADH}_{2}$ and release two electrons to the Fe-S clusters housed within subunit B. Assembly factors SDHAF1 and SDHAF2 assist in the maturation of subunits A and B. SDHAF1 provides Fe-S clusters to SDHB and SDHAF2 works in conjunction with dicarboxylate to stabilize the active site of SDHA. The next subunits, $C$ and $D$, house heme and are responsible for ubiquinone reduction to ubiquinol. From here, ubiquinol is transferred to complex III of the ETC. The three known pseudogenes of SDHA, SDHAP1-3, are also included, whose metabolic function is still unknown.

\subsection{Maturation and Assembly of the SDH Complex}

The SDH complex is assembled through different complex genes (Figure 1). SDHA is responsible for the catalyzation of succinate to fumarate. In order for SDHA to be functional, it is dependent on sufficient flavin adenine dinucleotide (FAD) levels because it is a cofactor. Advantages of FAD cofactor binding to SDHA include increased redox potential to permit sufficient catalytic activity and stability of the overall complex [13]. It has been found that SDHAF4 can serve as a chaperone of flavinylated SDHA by direct interaction prior to SDHA-SDHB complex formation by blocking excess reactive oxygen species (ROS) production [14]. The next subunit is $S D H B$, which stores Fe-S proteins; these proteins help transfer electrons from FAD to ubiquinone. Frataxin is a mitochondrial protein, and its deficiency can lead to Friedreich's ataxia and iron accumulation in the mitochondria [15]. Frataxin deficiency can reduce the activity of Fe-S proteins which as a result can compromise SDH function [16]. SDHAF1 and SDHAF3 support SDHB maturation by transferring Fe-S clusters and bypassing respiratory distress and supporting respiratory growth by shielding SDHB from the oxidants [17]. The final step in the assembly of the complexes includes anchorage of SDHC and SDHD. This anchorage serves as the site for ubiquinone binding and ubiquinone reduction to ubiquinol. The heme $b$ also sits in this domain but has been noted to not have a significant role in catalysis [18]. In mammalian structures, the heme $b$ supports the structure of the membrane anchorage domain [19].

\subsection{Metabolic Reactions of the SDH Complex}

The SDH complex plays a vital role in cell metabolism considering its participation in the TCA cycle and ETC. This functional unit allows for the maintenance of ROS. SDH is responsible for oxidizing succinate to fumarate through the FAD redox reaction in the TCA cycle. There are multiple electron transfer pathways that allow the TCA cycle and ETC to function. Electrons are transferred to the three Fe-S clusters throughout the SDH complex (complex II), and these clusters start to transfer the electrons to ubiquinone. This is in preparation for ubiquinone reduction. Electrons are transferred from the Fe-S clusters to the ubiquinone pool which allows electron transfer between complex II and complex III [20]. Complex II is responsible for the reduction of ubiquinone to a semiquinone intermediate to ubiquinol. Heme also has many roles within the cell and serves as a prosthetic group for mitochondrial respiratory complexes. As discussed before, heme does not have a major role in catalysis, but it is essential for SDH complex assembly. In mammalian cells mutations in SDHC H127A and SDHC H127Y resulted in the decreased level of SDHC, a decrease in enzyme activity, and inhibition of complex II assembly formation [21]. The ETC acts as a proton gradient with proton pumping through complexes I, III, and IV. Although complex II is not involved in proton pumping, there is internal protonation involved with catalysis.

\section{Pathogenesis of Succinate Dehydrogenase-Relevant Diseases and Mechanisms}

\subsection{Cancers}

Early studies linked SDH complex dysfunction with cancer, evidenced specifically by studies that showed that $S D H B$ [22], SDHC [23,24], and SDHD [22] mutations increased superoxide anion 
release (oxidative damage) which led to cells undergoing apoptosis or transformation. Recently, SDH is classified as a tumor suppressor, mostly due to two well-known abnormalities that it experiences, which allow for oncogenesis (Figure 2). First, SDH inactivation led to accumulation of succinate, which competitively inhibits HIF- $\alpha$ prolyl hydroxylase domain (PHD) and leads to the stabilization of HIF [25]. Stabilized HIF increases malignant cell proliferation by promoting angiogenesis [25] and ROS production [2]. Increased levels of succinate also led to the production of ROS by inhibiting $\alpha$-ketoglutarate-dependent enzymes [26] and increasing the reverse flow of electrons from complex II to complex I [27]. Furthermore, the accumulation of succinate leads to increased histone methylation via binding directly and inhibiting histone demethylase JumonjiD3, which enhances epigenetic changes and oncogenic transformation [28]. We will discuss mutations in the SDH complex that reconfigure the aforementioned cellular mechanisms to induce tumorigenesis for certain cancers and their roles in other diseases.

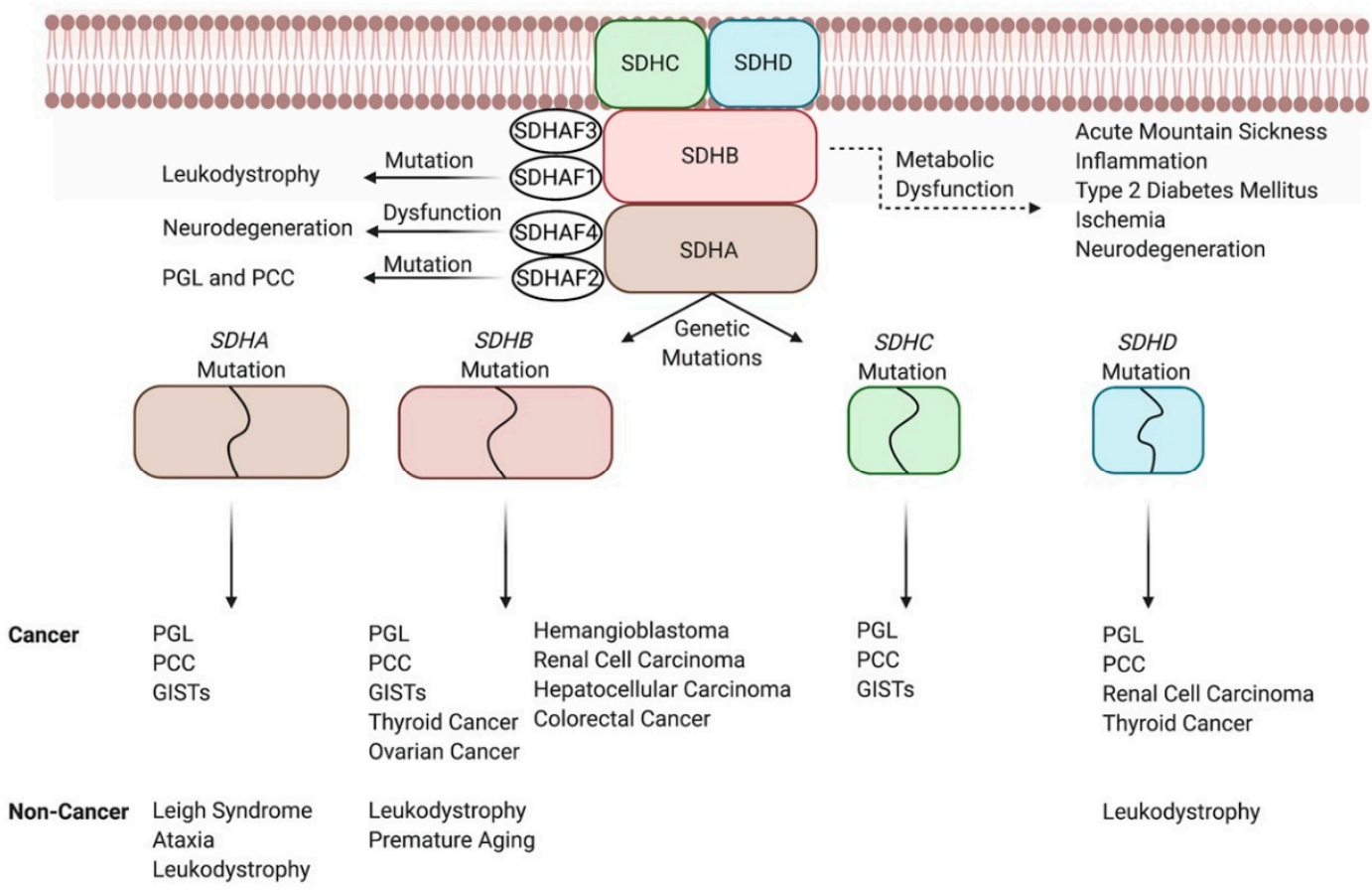

Figure 2. Genetic and metabolic dysfunction of the SDH complex and its link to diseases. For instance, SDHB mutations lead to the development of paraganglioma (PGL), pheochromocytoma (PCC), ovarian cancer, colorectal cancer, gastrointestinal tumors (GISTs), and other cancers. Similarly, SDHB mutations can cause non-cancer diseases such as leukodystrophy and premature aging. Another way that abnormal SDH activity causes the disease is through its metabolic dysfunction, as seen with decreased activities of SDHA and SDHB through epigenetic modification causing acute mountain sickness.

\subsubsection{Paraganglioma and Pheochromocytomas}

Mutations in SDHB [29], SDHC [30], and SDHD [31] have been implicated in causing two rare tumors in the autonomic nervous system known as paraganglioma (PGL) and pheochromocytoma (PCC) [32]. All of these specific genetic mutations are known to increase ROS production [22], which leads to DNA damage and tumorigenesis [33]. Interestingly, SDHB [22] and SDHD [34] mutations increased ROS production, which led to the onset of PGL and PCC through the stabilization of HIF mode of action. Mutations in all four subunits of $S D H$ encoding genes have been shown to cause PCC and PGL through the inhibition of the histone demethylation route [28]. Interestingly, the same study found that $S D H B$ mutations had a stronger effect in inhibiting histone methylases which allowed for increased hypermethylation [28]. This could explain why SDHB-mutated PGL and PCC are more malignant than when caused by mutations in other SDH-encoding subunits [35]. More recently, a group 
of researchers found that mutations of SDHAF2 alone [36] were linked to PGL and PCC, despite research suggesting that SDHAF2 does not cause PGL and PCC through the inhibition of histone demethylation way of action [28]. However, no mechanism has yet been discovered. It is important to note that PGL and PCC are the tumor types most commonly associated with inheritance/germline mutations, specifically in the aforementioned SDH subunits [37], which highlights the dynamic role germline and somatic mutations within the SDH complex have in causing cancers and the importance of genetic counseling for the former.

\subsubsection{Other Cancers}

PGL and PCC are most commonly associated with SDH mutations, but other cancers may also arise due to either SDH mutations or reduced SDH activities (Figure 2). For example, SDHB silencing led to increased levels of HIF- $1 \alpha$ and adenosine monophosphate-activated protein kinase which promoted metastasis in ovarian cancer [38]. Likewise, the decrease in SDHB in hepatocellular carcinoma increased its malignancy through the Warburg effect and increased expression of epithelial-mesenchymal transition-related markers [39]. In colorectal cancer, wild-type SDHB has been shown to increase expressions of tumor suppressors such as phosphatase and tensin homolog (PTEN), caveolin-1, and cullin-5 to arrest the cell cycle, but its mutation led to increased cell division [40]. Carney-Stratakis syndrome, caused by germline mutations in SDHA-B-C-D, has been linked to causing PGL and GIST [41,42]. Specifically, SDH deficiency promoted DNA hyper-methylation at sites near the fibroblast growth factor 4 and tyrosine-protein kinase kit oncogenes, which led to their activation and the onset of GIST [43]. Although specific mechanisms such as the one elucidated for GISTs are not yet available, research has implicated SDHB and SDHD [44] mutations in renal cell carcinoma and thyroid tumors, SDHB defects [45] in pituitary adenomas, and loss of SDHB [46] in hemangioblastoma. The lack of established mechanisms for these cancers is highlighted specifically in the study attributing SDHB mutation to hemangioblastoma. Overall, there are few cases of hemangioblastoma, with only 19 of the total 35 patients testing positive for $S D H B$ mutation [46]. The study stops short of conducting other experiments such as epigenetic analysis. Collectively, these issues do not allow for the relationship between SDHB inactivation and hemangioblastoma to be fully elucidated and similar issues arise when studying other $S D H$ mutations and other cancers. Altogether, our understanding of the role of SDH between PGL and PCC and other cancers varies, but further research could provide therapeutic targets of SDH against cancer.

\subsection{High-Altitude Illness (Acute Mountain Sickness)}

Acute mountain sickness (AMS) is a result of the decreased partial pressure of oxygen at higher altitudes that causes tissue hypoxia [47]. The effects of AMS-induced hypoxia on mitochondrial function has been studied [48], with a consensus that oxidative damage increases with high altitude [49]. This is due to high altitude exposure increasing ROS production at complex I and complex III of the ETC, due to reduced electron flow $[49,50]$. Interestingly, $\mathrm{Lu}$ et al. compared AMS resistant individuals to AMS susceptible individuals and found that those resistant to AMS decreased plasma succinate levels through attenuation of SDHA and SDHB along with succinate-CoA ligase [51] (Figure 2). Succinate-CoA ligase is a key enzyme involved in converting succinyl-CoA to succinate through the following subunits: succinate-CoA ligase GDP/ADP-forming subunit alpha (SUCLG1), succinate-CoA ligase GDP-forming subunit beta (SUCLG2), and succinate-CoA ligase ADP-forming subunit beta (SUCLA2) $[52,53]$. The study suggested that the aforementioned genes were silenced due to exposure to high altitude, with the exact mechanisms yet to be discovered [51]. Similarly, PGL exhibits the same environmental and genetic crosstalk seen in AMS as prolonged exposure to high altitudes led to a mutation in SDHB which caused PGL in patients [54]. A clear link is shown between high-altitude, $\mathrm{SDH}, \mathrm{AMS}$, and cancer, and further research could be beneficial for a better understanding of this intricate connection. 


\subsection{Inflammation}

SDH has shown the capability to play key roles in pro- and anti-inflammatory signaling (Figure 2). For instance, lipopolysaccharide-stimulated interleukin 1 beta (IL-1 $\beta$ ) release in macrophages promotes inflammation via increased succinate levels, resulting in PHD-mediated HIF-1 $\alpha$ accumulation [55] or SDH-catalyzed ROS production [56]. IL-1 $\beta$ can also be produced independent of HIF-1 $\alpha$ through the inflammatory release of succinate by macrophages which activates succinate receptor 1 (SUCNR1)/G-protein coupled receptor 91 (GPR91) and enhances the adverse effects of rheumatoid arthritis [57]. Conversely, inflammatory mononuclear phagocytes increase succinate levels to stimulate SUCNR1/GPR91 which allows uptake of succinate by neural stem cells, and their subsequent anti-inflammatory phenotype through reduction of IL-1 $\beta$ [58]. As exhibited, succinate has a role in the inflammatory response of cells, and further research can provide therapeutic options as seen with SUCNR1/GPR91 inhibitors for rheumatoid arthritis [57].

\subsection{Neurodegenerative Disease}

SDH has an important role in electron flow [19,59], exemplified by SDH activity causing electron carriers such as nicotinamide adenine dinucleotide (NAD) to not be oxidized which in turn leads to a decrease in electron flow to complex III and ubiquinone, and the production of ROS [60]. Mutations in SDHA have been shown to lead to this mechanism and the development of Leigh syndrome [61,62]. Other mutations of $S D H$ subunits that have been implicated in neurodegenerative diseases include SDHA causing ataxia [63] and SDHA [64], SDHB [64], SDHD [65], and SDHAF1 [66] leading to leukodystrophy, yet these studies have been limited to few patients (Figure 2). Nevertheless, as stated in a recent review paper [67], succinate is linked with the mammalian target of rapamycin (mTOR) [68], a kinase involved with a plethora of neurodegenerative diseases [69]. This provides interest for further studying roles of succinate in neurodegenerative diseases, especially since SDHAF4 has been shown to stabilize succinate accumulation, increase mitochondrial SDH activity, while limiting ROS production and preventing neurodegeneration in drosophila [14].

\subsection{Diabetes}

The succinate mechanism of insulin release states that high mitochondrial levels of succinate produce mevalonic acid, which triggers insulin release in pancreatic islet cells (refer to source paper for full mechanism) [70]. Proteomic analyses of type 2 diabetes mellitus (T2D) patients with chronic hyperglycemia showed that increased glucose levels led to inhibition of the ETC. This is due to decreased expression of SDH along with citrate synthase and fumarate hydratase in the mitochondria, which led to decreased insulin release of pancreatic $\beta$-cells [71]. While succinate levels decrease in the mitochondria, circulating levels of succinate have been shown to increase in T2D patients [72]. This circulating succinate can accumulate in the diabetic kidney, leading to succinate induced activation of GPR91, a receptor that activates the renin-angiotensin system [73]. The activation of renin-angiotensin system in diabetic rats has been linked to induced hypertension and nephropathy [74]. Further research of succinate's role in diabetes is encouraged as a link has already been established.

\subsection{Ischemia-Reperfusion Injury}

Succinate is known to accumulate during cardiac ischemia, which is then consumed during reperfusion and leads to oxidative damage due to increased ROS production [75]. A leading model to explain this phenomenon is the upregulation of glycolysis and the TCA cycle, known to occur during ischemia. These two processes drive the conversion of glutamate to 2-oxoglutarate, which is then synthesized into succinate through succinate-CoA ligase [76]. Barth syndrome, a genetic disease known to cause cardiomyopathy, leads to the loss of SDH in cardiac tissue and a subsequent increase in ROS production [77]. Although cardiac ischemia and Barth syndrome are not caused by succinate, 
their effect on succinate has unfavorable consequences, and research of the effect of non-SDH induced diseases on SDH dysfunction is a topic warranting further analysis.

\section{A Network of RNA Regulators Interacting with Succinate Dehydrogenase}

\subsection{Non-Coding RNAs}

Non-coding RNAs are transcribed RNAs known for their regulatory function on mRNA [78] and their ability to affect several cellular processes to influence disease states [79-82]. Non-coding RNAs include microRNAs (miRNAs), small non-coding RNAs (sRNAs), long non-coding RNAs (lncRNAs), and circular RNAs among others [78]. Numerous non-coding RNAs, especially miRNAs, have been shown to target $\mathrm{SDH}$ and lead to disease. In lung cancer, increased expression of miR-147b [6] downregulates $\mathrm{SDH}$ and leads to drug tolerance to epidermal growth factor receptor tyrosine kinase inhibitor, while upregulated miR-210 [5] lowers the enzymatic activity of SDHD to stabilize HIF- $1 \alpha$. miR-31 was found to suppress SDHA expression in induced pluripotent stem cells to initiate the Warburg effect [83]. An expression profile study found that miR-124 can inhibit the conversion of succinate to succinyl-CoA by downregulating SUCLG2 [84], showing that other miRNAs could affect $\mathrm{SDH}$ and perhaps other diseases. The sRNA, NrrF, after binding with the Hfq protein, binds to the sdhCDAB mRNA transcript in N. meningitidis and upregulates SDHA, SDHB, SDHC, and SDHD [85]. Crosstalk between miR-488-3p and the lncRNA Cerox1 regulates mitochondrial complex I activity, showing promise that interactions between non-coding RNAs may affect the SDH complex [86]. Altogether, non-coding RNAs have been shown to affect SDH levels and even modulate disease progression (Figure 3).

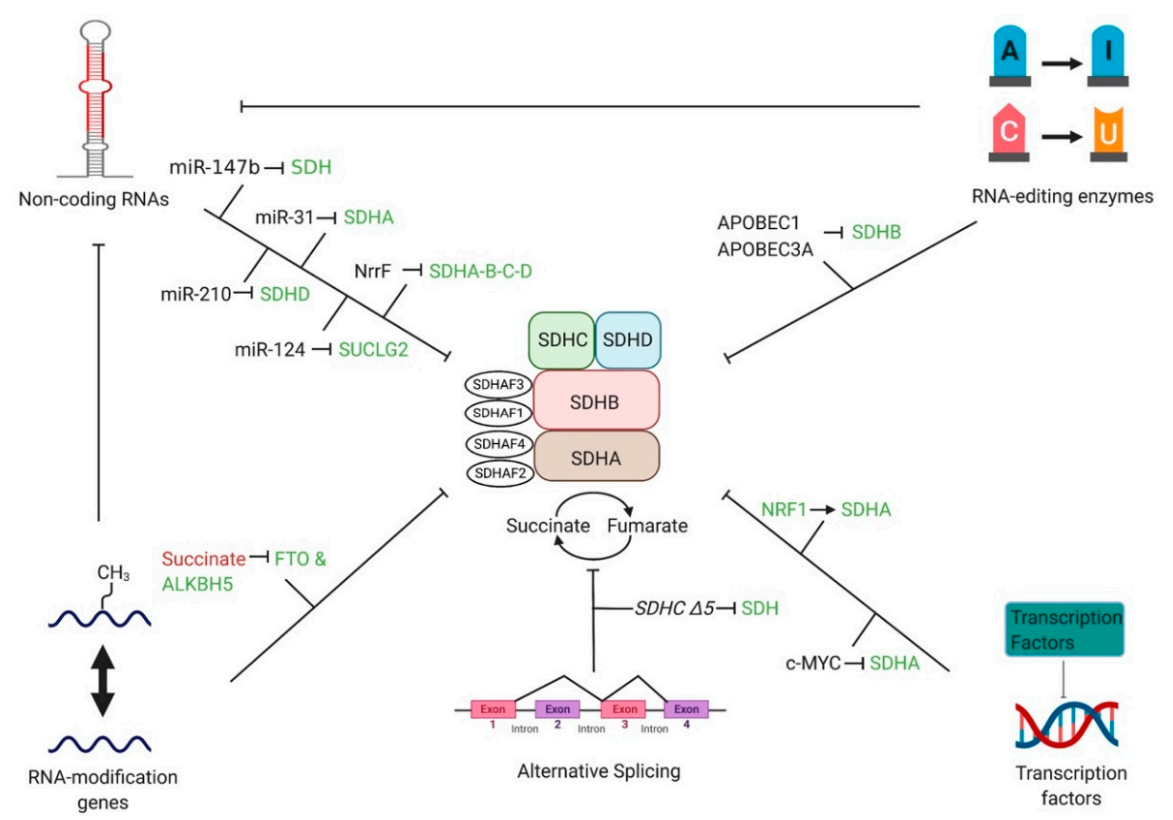

Figure 3. A network of RNA regulators interacting with succinate dehydrogenase. Different proteins/processes affecting the transcription/translation of the SDH complex are shown. For example, the RNA-editing enzyme APOBEC3A decreases the expression of SDHB. Similarly, the non-coding RNAs miR-31 and miR-210 decrease SDHA and SDHD activity, respectively. It is important to note that the interplay between RNA-editing enzymes and RNA-modification genes with non-coding RNAs has been established, but the possible role of these regulators and their effect on SDH has yet to be discovered and warrants intrigue. Regulations are signified with inhibition $(-1)$ and promotion $(\rightarrow)$ together with upregulation (red lettering) and downregulation (green lettering). 


\subsection{RNA-Editing Enzymes}

RNA editing is a posttranscriptional mechanism that involves the alteration of RNA sequences through insertions, deletions, or substitutions done by enzymes [87]. To date, the two well-known RNA editing enzymes, adenosine deaminases acting on RNA (ADARs) $[88,89]$ and apolipoprotein B mRNA editing enzyme, catalytic polypeptide-like (APOBEC) [90], cause adenine to inosine (A-to-I) and cytidine to uracil (C-to-U) editing on RNA transcripts, respectively. Hypoxic conditions in peripheral blood mononuclear cells, along with their differentiation into macrophages, led to increased C-to-U editing by apolipoprotein B mRNA editing enzyme catalytic subunit 1 (APOBEC1), a member of the APOBEC family. This caused a nonsense mutation and the inactivation of the SDHB gene [91] (Figure 3). Continuously, Baysal's lab demonstrated for the first time that another APOBEC family member APOBEC3A modifies SDHB RNA in monocytes and macrophages via a C-to-U editing mechanism that is activated by hypoxia or interferons [92]. Section 3 of this review describes different ailments such as cancer caused by mutations in $S D H$ subunits, including $S D H B$, which signifies the importance of studying the effects of RNA-editing enzymes on SDH. It is important to note that RNA editors can also affect the processing of non-coding RNAs, as seen with increased A-to-I editing in miR-376 which changes the targets of miR-376 [93]. The role of RNA editors in miRNAs and other non-coding RNAs that subsequently affect SDH is a topic that is yet to be investigated but is an exciting prospect. This is of significant interest to further study the effects of APOBEC and ADAR due to its wide-ranging effects on SDH-affecting genes.

\subsection{RNA-Modification Genes}

$\mathrm{N}^{6}$-methyladenosine $\left(\mathrm{m}^{6} \mathrm{~A}\right)$ modification of mRNA is the most abundant RNA modification and plays a pivotal role in determining gene expression [94]. Fat mass and obesity-associated protein (FTO) and alpha-ketoglutarate-dependent dioxygenase AlkB homolog 5 (ALKBH5) are two well-characterized $\mathrm{m}^{6} \mathrm{~A}$ erasers that reverse the actions of writers for $\mathrm{m}^{6} \mathrm{~A}$ through demethylation [95]. These $\mathrm{m}^{6} \mathrm{~A}$ erasers are also identified as 2-oxoglutarate-dependent oxygenases. Inactivating $\mathrm{SDH}$ mutations induces succinate accumulation, a product that competes with 2-oxoglutarate and hence may inhibit the expression of FTO and ALKBH5 [96]. Similar to RNA editors, the role between RNA-modifiers and non-coding RNAs has been elucidated (and its role in causing cancer) [97] (Figure 3). It is crucial to investigate whether an interplay exists between RNA modifiers and non-coding RNAs that impact SDH activity. Overall, it is critical to study the relationship between SDH complex dysfunction and $\mathrm{m}^{6} \mathrm{~A}$ erasers as the latter's depletion has been linked to diseases such as male-infertility [98].

\subsection{Transcription Factors}

Transcription factors play an intricate role in gene expression as they activate or repress transcription of DNA into RNA [99], and its misregulation has been implicated to cause disease [100]. Nuclear respiratory factor 1 (NRF1) silencing attenuated SDHA expression at transcriptional levels in cardiac cells, causing complex II dysfunction, which had a final effect of decreased PHD activity leading to hypoxia response through HIF-1 $\alpha$ stabilization [101] (Figure 3). MYC enhances S-phase kinase associated protein 2 (SKP2) activity, a proteasome that degrades SIRT3 deacetylase, which led to increased acetylation of SDHA and its subsequent silencing [102]. MYC-mediated dysfunction of SDH activity led to succinate accumulation and increased H3K3me3 modification on histones [102]. Overall, this modification promoted tumor progression in Burkitt's lymphoma cell lines, but the specific genes that were downregulated to cause this effect were not mentioned [102]. Here, we show that increased and decreased activity of MYC and NRF1, respectively, modulate disease states through transcriptional effects on SDH subunits. 


\subsection{Alternative Splicing}

The manipulation of the order of exons in mature mRNA due to alternative splicing mechanisms is well known to alter gene expression [103]. In SDH, the SDHC $\Delta 5$ isoform which lacks exon 5 , formed by alternative splicing mechanisms, decreased SDH activity by $40 \%$. This led to a notable increase in the production of ROS [104] (Figure 3). However, another isoform of $S D H C(\Delta 3)$ had a marginal effect on SDH activity and only minimal ROS production [104]. Nevertheless, alternative splicing in SDH subunits provides another plausible explanation of how SDH subunit dysfunction can lead to disease.

\section{Treatment against Succinate Dehydrogenase Dysfunction}

\subsection{Small Molecules Inducing or Blocking SDH Activity}

While the study of mitochondrial regulation and SDH has been around for over 100 years, still little is known about the details of the molecular pathways taken by SDH activators and inhibitors. SDH is regulated through the genetic level and three distinct binding sites. These sites have been exploited for use from fungicides to tumor cell regulation.

\subsubsection{SDH Inhibitors}

There are two distinct classes of metabolic SDH inhibitors based on where the inhibitor binds. $\mathrm{SDH}$ inhibitors either bind in the ubiquinone pocket at the proximal $\left(\mathrm{Q}_{\mathrm{p}}\right)$ or distal $\left(\mathrm{Q}_{\mathrm{D}}\right)$ binding sites, or in the succinate pocket [105]. Briefly, binding to the ubiquinone pocket affects the reduction of ubiquinone to ubiquinol which is a part of the ETC. Additionally, binding to the succinate pocket influences the enzymatic activity of SDH inside of the TCA cycle [106] (Figure 4).

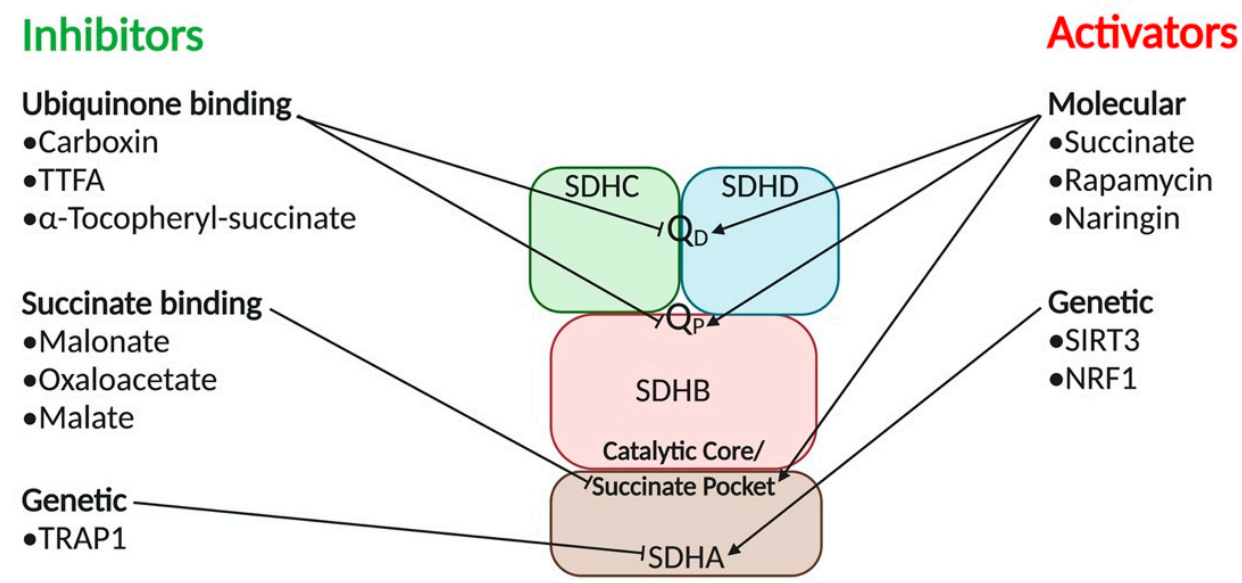

Figure 4. Strategies for Targeting Succinate Dehydrogenase Complex. Ubiquinone binding inhibitors carboxin, TTFA, and $\alpha$-Tocopheryl succinate bind and deactivate SDH at the proximal $\mathrm{Q}_{\mathrm{P}}$ and distal $\mathrm{Q}_{\mathrm{D}}$ ubiquinone binding sites. Ubiquinone binding inhibitors disrupt the reduction of ubiquinone to ubiquinol, a key step in the ETC. Succinate binding inhibitors malonate, oxaloacetate, and malate bind at the catalytic core or succinate pocket of SDH. Succinate pocket inhibitors are typically intermediates from the TCA cycle that modulate SDH activity based on cellular needs. Genetic inhibitor TRAP1 is a mitochondrial chaperone that inhibits SDH functions causing hypoxic environments that stimulate tumorigenesis. SDH activators such as succinate, Rapamycin, and Naringin function as small molecules activators of SDH. Additionally, genetic activator SIRT3 regulates the deacetylation of SDHA. NRF1 is an oxygen-sensing protein that binds to SDH genetic promoters when there is a lack of oxygen to limit ETC energy production until suitable oxygen conditions are resumed.

Carboxin is a ubiquinone inhibitor commonly used as a fungicide. Thenoyltrifluoroacetone (TTFA) is another ubiquinone SDH inhibitor that was originally thought to be a chelating agent [107]. After the development of $19 \mathrm{SDH}$ inhibitors, it was determined that all of them share a carbonyl 
center, a conserved amide function, and an amine functional group. Yao et al. took these common groups and applied in silico library design and pharmacophore mapping to create potential novel inhibitors. A16c showed to be the most promising inhibitor from this study, with increased potency against standard fungal targets [108]. Genetic regulation of SDH subunits has also been documented. SDHB expression has been shown to be lowered in maize leaves related to the amount of light present [109]. This is due to the reduced need for energy from the TCA cycle when photosynthesis is occurring. $\mathrm{SDH} 2-3$ gene function was downregulated in response to the lower expression of the phytochrome interacting factor 3 gene, which is involved in several developmental processes of plants. SDH inhibitors have been used as fungicides since the 1960s, but recently there has been a surge in SDH inhibitors as a cancer therapeutic strategy.

The human application of SDH inhibitors is still in its early stages. SDH inhibitors functioning as fungicides have been difficult to bring to human use mainly due to the cellular similarities between fungi and humans causing cytotoxicity. TTFA, the original SDH inhibitor, was shown to induce cell apoptosis in neuroblastoma cells [110]. Alpha-Tocopheryl succinate, a similar compound to vitamin E, is another SDH inhibitor shown to induce cell apoptosis in cancer cell lines via binding to the $Q_{P}$ and $Q_{D}$ [111]. Malonate, a synthetic compound, has been used as an SDH inhibitor to limit reperfusion injury and infarct size in mice and pig hearts [112]. TCA cycle intermediates oxaloacetate and malate are strong inhibitors of SDH binding to its catalytic site [113]. Mitochondrial chaperone tumor necrosis factor receptor associated protein 1 (TRAP1) has been identified as an inhibitory SDHA binding protein that is overexpressed in many types of cancers [114]. TRAP1 binding to SDHA decreases SDH activity and limits mitochondrial-dependent respiration in cancer cells. The reduced SDH activity-induced succinate accumulation leads to hypoxic response via activating HIF- $1 \alpha$. This scenario allows tumor cells to survive nutrient-depleted environments and oxidative stress [115].

\subsubsection{SDH Activators}

$\mathrm{SDH}$ can be activated on both metabolic and genetic fronts. On the metabolic front, succinate activates the catalytic function of SDH through dissociating any SDH inhibitors such as oxaloacetate and malate in the TCA cycle [116]. Rapamycin is currently being studied as a potential treatment against SDH deficiency. Exposing flies with mutated SDHA and SDHB to rapamycin improved the enzymatic activity of SDH through the inhibition of the mTOR pathway [117]. In addition, naringin, a bioflavonoid found in citrus fruit peel, restored SDH enzymatic activity that was impaired by D-galactose via influencing ROS [118] (Figure 4). In the ETC, there is a balance of phosphorylation and acetylation contributing to the activity of SDH [119]. The less acetylation and phosphorylation present, the more active SDH is. Sirtuin-3 (SIRT3) is the primary deacetylase for SDHA and is the main contributor to the catalytic ability of SDH inside the ETC [120]. This NAD-dependent enzyme mediates the reversible acetylation of SDHA through post-translational modifications (Figure 4). NRF1 has been shown to bind to the promoters of the SDHA and SDHD genes in aerobic rat cardiac cells resulting in increased expressions of SDHA and other subunits of SDH complex. This binding is a response to a lack of oxygen where the cell relies on glycolytic ATP production until suitable conditions resume for ETC production of ATP [101]. Additionally, reduced SDH expression is inversely related to promoter methylation of $S d h 1-2$ which encode for SDHA in maize under anoxic conditions [121].

\subsection{CRISPR}

Clustered regularly interspaced short palindromic repeats (CRISPR) is a powerful gene-editing tool [122]. Recent studies have shown the effects of editing different SDH subunits and the effect on certain diseases. For example, the downregulation of SDHC using CRISPR in breast cancer cell lines correlated with a smaller amount of the cancer cells undergoing epithelial to mesenchymal transition [123]. 


\section{Pre-Clinical Models and Clinical Trials for Succinate Dehydrogenase}

\subsection{Approaches to Measuring SDH Activity}

SDH activity can be measured using many different approaches. The Succinate Dehydrogenase Assay Kit is a colorimetric assay designed to measure SDH activity in tissue culture or purified mitochondrial samples. The assay detects the production of fumarate from succinate by SDH. Fumarate hydratase converts fumarate to malate and then malic dehydrogenase converts malate to pyruvate and nicotinamide adenine dinucleotide phosphate $\left(\mathrm{NADP}^{+}\right)$to nicotinamide adenine dinucleotide phosphate hydrogen (NADPH) which is detected spectrophotometrically [124]. SDH activity can also be measured using a redox dye such as an artificial electron acceptor reporter module 2,6-dichlorophenolindophenol (DCPIP). In a conversion from succinate to fumarate, SDH transfers the electron to oxidized DCPIP, which changes the color from blue to the pink or colorless product. By adding surface-enhanced Raman scattering, results can be specified and a more accurate level of SDH activity can be determined [125]. SDH levels have also been measured using a microphotometric assay coupled with human muscle samples [126]. This assay uses nitro blue tetrazolium (NBT) to bind to mitochondria and function as a final electron acceptor. The enzymatic activity of SDH can then be measured by taking absorbances at certain time points to create a reaction curve [127].

\subsection{Pre-Clinical Models}

SDH has been studied in plants since the 1960s. Plants are advantageous in that they have all four SDH subunits and SDH serves a similar role in the TCA cycle and ETC as in humans. The disadvantage of plants is that they contain four accessory subunits, SDH5-SDH8 [128]. These accessory subunits are not conserved in humans and their specific functions are unknown. The plant SDH3 and SDH4 lack sequences that help it bind to SDH1. Similar sequences have been found in plant SDH6 and SDH7 that could help stabilize the complex. SDH5 is a more hydrophobic subunit that interacts with SDH2 and SDH4, but its function is unknown. SDH8 is the least understood accessory subunit. The subunit is only $4.9 \mathrm{kDa}$ in size and does not show any similar sequences in the current genome mapping to any other SDH subunits [129].

Yeast contains the same subunits as other eukaryotic organisms. Yeast is advantageous over other organisms because both respiratory and fermentative metabolism can be observed in the same model. Yeast has also been shown to recreate human SDH mutations specifically in SDHB and SDHC. This ability allows researchers to study the specific mutations in detail in a preclinical model not typically available in other organisms [130].

Most studies conducted with Escherichia coli focus on the adaptation to changing oxygen environments and the gene expressions related to the changes. Through the E. coli study, it has been determined that the alpha-ketoglutarate dehydrogenase and succinyl coenzyme A synthase are regulated by SDHC. These enzymes are important in the TCA cycle component of SDH metabolism. E. coli as a preclinical model is beneficial because of its easily manipulated genome [131].

Caenorhabditis elegans, commonly referred to as the nematode, is beneficial as a preclinical model because of its thoroughly understood development, small genome, and short, complete life [132]. In SDH research, the nematode has been used to study mutations in SDHB leading to tumorigenesis. The study found that the ubiquinone-binding site of SDH became a significant source of superoxide, but the effects were abrogated with the administration of antioxidants [133].

The transgenic mouse is one of the most advanced preclinical models to investigate tumorigenesis and other pathologies contributed to SDH mutations. Piruat and Millan-Ucles demonstrated knockout mouse models for each SDH subunit gene and how it affected development [134]. Other mouse models have also linked $S D H$ mutations to tumorigenesis through oxygen-depleted environments and epithelial to mesenchymal transition [135]. Preclinical models can show a general direction on how a clinical trial will go and account for metabolic environments not replicable in vitro. These models are a critical testing ground for higher stakes clinical trials. 


\subsection{Clinical Trials}

Clinical trials associated with SDH dysfunction range from advanced cancers to neurodegeneration (Table 1). The broader study of mitochondrial dysfunction also accounts for many clinical trials where SDH dysfunction plays a role.

Table 1. SDH relevant clinical trials.

\begin{tabular}{|c|c|c|c|}
\hline Study Title & Description & $\begin{array}{l}\text { Dates (Start-Completion) } \\
\text { and Status }\end{array}$ & $\begin{array}{l}\text { Identifier and Study } \\
\text { Type (Enrollment) }\end{array}$ \\
\hline \multicolumn{4}{|l|}{ Cancers } \\
\hline $\begin{array}{l}\text { An Open-Label, Phase } 2 \\
\text { Efficacy Study of } \\
\text { Temozolomide (TMZ) In } \\
\text { Advanced Succinate } \\
\text { Dehydrogenase } \\
\text { (SDH)-Mutant/Deficient } \\
\text { Gastrointestinal Stromal } \\
\text { Tumor (GIST) }\end{array}$ & $\begin{array}{l}\text { Therapies already exist for } \\
\text { advanced GIST, but they are } \\
\text { not effective against SDH } \\
\text { mutant subtypes of GIST. } \\
\text { TMZ is already approved for } \\
\text { the treatment of other } \\
\text { glioblastoma tumors, but its } \\
\text { effect on SDH mutant GIST } \\
\text { has not been previously } \\
\text { studied. }\end{array}$ & $\begin{array}{l}\text { September 2018-September } \\
2024 \text { (Recruiting) }\end{array}$ & $\begin{array}{l}\text { NCT03556384 } \\
\text { Interventional (N.A.) }\end{array}$ \\
\hline $\begin{array}{l}\text { A Phase II Trial of the } \\
\text { DNA Methyl Transferase } \\
\text { Inhibitor, Guadecitabine } \\
\text { (SGI-110), in Children } \\
\text { and Adults with Wild } \\
\text { Type GIST, } \\
\text { Pheochromocytoma and } \\
\text { Paraganglioma } \\
\text { Associated with } \\
\text { Succinate } \\
\text { Dehydrogenase } \\
\text { Deficiency and } \\
\text { HLRCC-associated } \\
\text { Kidney Cancer }\end{array}$ & $\begin{array}{l}\text { To determine the overall } \\
\text { response to SGI-110 in tumor } \\
\text { growth and effects on the } \\
\text { body. GIST is resistant to } \\
\text { conventional radiation or } \\
\text { chemotherapy treatments. } \\
\text { Imatinib is the current } \\
\text { standard of care but } \\
\text { tumor-developed resistance } \\
\text { and mutations are becoming } \\
\text { more prevalent. SGI-110 is } \\
\text { targeting these tumors by } \\
\text { preventing DNA } \\
\text { methylation and has shown } \\
\text { to be effective against } \\
\text { imatinib resistant GIST. }\end{array}$ & $\begin{array}{l}\text { May 2017- } \\
\text { February } 2020 \text { (Completed) }\end{array}$ & $\begin{array}{l}\text { NCT03165721 } \\
\text { Interventional (9) }\end{array}$ \\
\hline $\begin{array}{l}\text { Ph1 Study of the Safety, } \\
\text { PK, and PDn of } \\
\text { Escalating Oral Doses of } \\
\text { the Glutaminase } \\
\text { Inhibitor CB-839, as a } \\
\text { Single Agent and in } \\
\text { Combination with } \\
\text { Standard Chemotherapy } \\
\text { in Patients with } \\
\text { Advanced and/or } \\
\text { Treatment-Refractory } \\
\text { Solid Tumors }\end{array}$ & $\begin{array}{l}\text { Tumor cells have been } \\
\text { shown to be dependent on } \\
\text { glutamine for cellular } \\
\text { respiration. Because this is a } \\
\text { unique trait to tumors, this } \\
\text { dependence serves as a } \\
\text { potential therapeutic target. } \\
\text { CB-839 is a highly specific } \\
\text { inhibitor targeting } \\
\text { glutaminase, the first } \\
\text { enzyme involved in } \\
\text { glutamine utilization. This } \\
\text { study looks at the potency of } \\
\text { this inhibitor across a wide } \\
\text { range of tumors. }\end{array}$ & $\begin{array}{l}\text { February 2015- } \\
\text { March } 2019 \\
\text { (Completed) }\end{array}$ & $\begin{array}{l}\text { NCT02071862 } \\
\text { Interventional (210) }\end{array}$ \\
\hline $\begin{array}{l}\text { A Phase } 2 \text { Open-Label } \\
\text { Study of Nivolumab } \\
\text { Combined with } \\
\text { Cabozantinib in Subjects } \\
\text { with Advanced or } \\
\text { Metastatic Non-Clear } \\
\text { Cell Renal Cell } \\
\text { Carcinoma (CA209-9KU) }\end{array}$ & $\begin{array}{l}\text { Nivolumab is a programmed } \\
\text { cell death protein } 1 \text { inhibitor, } \\
\text { and cabozantinib is a } \\
\text { tyrosine kinase inhibitor. } \\
\text { Both drugs are approved } \\
\text { treatments against several } \\
\text { types of metastatic kidney } \\
\text { cancers, but there are limited } \\
\text { data on combination } \\
\text { treatments using these two } \\
\text { drugs. }\end{array}$ & $\begin{array}{l}\text { August 2018-August } 2021 \\
\text { (Recruiting) }\end{array}$ & $\begin{array}{l}\text { NCT03635892 } \\
\text { Interventional (N.A.) }\end{array}$ \\
\hline
\end{tabular}


Table 1. Cont.

\begin{tabular}{|c|c|c|c|}
\hline Study Title & Description & $\begin{array}{l}\text { Dates (Start-Completion) } \\
\text { and Status }\end{array}$ & $\begin{array}{l}\text { Identifier and Study } \\
\text { Type (Enrollment) }\end{array}$ \\
\hline $\begin{array}{l}\text { Impact of Environmental } \\
\text { Exposures on Tumor } \\
\text { Risk in Subjects at Risk } \\
\text { of Hereditary SDHx } \\
\text { Paraganglioma } \\
\text { (PGL-EXPO-1) }\end{array}$ & $\begin{array}{l}\text { By studying environmental } \\
\text { and professional factors of } \\
\text { patients with an } S D H x \\
\text { mutation and comparing it } \\
\text { to a patient with the same } \\
\text { sex, age, and type of gene } \\
\text { affected but no tumor } \\
\text { progression, researchers } \\
\text { hope to identify novel } \\
\text { contributors to } S D H x \text { genetic } \\
\text { mediated tumor progression. }\end{array}$ & $\begin{array}{l}\text { January 2021-December } 2022 \\
\text { (Not yet recruiting) }\end{array}$ & $\begin{array}{l}\text { NCT04481152 } \\
\text { Observational (N.A.) }\end{array}$ \\
\hline \multicolumn{4}{|l|}{ Non-cancer } \\
\hline $\begin{array}{l}\text { Relationship Between } \\
\text { Succinate } \\
\text { Dehydrogenase } \\
\text { Mutations and } \\
\text { High-Altitude Illness } \\
\text { Associated with } \\
\text { Chemoreflex Failure }\end{array}$ & $\begin{array}{l}\text { SDH dysfunction is known } \\
\text { to cause hypoxia. At high } \\
\text { altitudes where oxygen is } \\
\text { limited, a cell already coping } \\
\text { with SDH dysfunction } \\
\text { would be overwhelmed. The } \\
\text { chemoreflex causes } \\
\text { hyperventilation when the } \\
\text { pressure of oxygen falls in } \\
\text { the blood. A dysfunctional } \\
\text { chemoreflex can lead to } \\
\text { pulmonary and cerebral } \\
\text { edema at high altitudes. }\end{array}$ & $\begin{array}{l}\text { March 2005-December } 2006 \\
\text { (Completed) }\end{array}$ & $\begin{array}{l}\text { NCT00202683 } \\
\text { Observational (83) }\end{array}$ \\
\hline $\begin{array}{l}\text { North American } \\
\text { Mitochondrial Disease } \\
\text { Consortium Patient } \\
\text { Registry and } \\
\text { Biorepository (NAMDC) }\end{array}$ & $\begin{array}{l}\text { The NAMDC is building an } \\
\text { international network of } \\
\text { researchers, patients, and } \\
\text { data to help both the } \\
\text { researcher and patient } \\
\text { connect with the proper } \\
\text { clinical trials and potential } \\
\text { treatments. }\end{array}$ & $\begin{array}{l}\text { December 2010-December } \\
2025 \text { (Recruiting) }\end{array}$ & $\begin{array}{l}\text { NCT01694940 } \\
\text { Observational (N.A.) }\end{array}$ \\
\hline $\begin{array}{l}\text { Targeting Glutamine } \\
\text { Metabolism to Prevent } \\
\text { Diabetic Cardiovascular } \\
\text { Complications } \\
\text { (GLUTADIAB) }\end{array}$ & $\begin{array}{l}\text { This study has broad } \\
\text { metabolic implications and } \\
\text { serves as the starting point } \\
\text { for several secondary studies. } \\
\text { After glutamine metabolism } \\
\text { is better understood in its } \\
\text { role in the inflammatory } \\
\text { response, several other } \\
\text { factors will be analyzed } \\
\text { including SDH-controlled } \\
\text { intermediates. RNA } \\
\text { modification will also be } \\
\text { utilized to target monocytes. }\end{array}$ & $\begin{array}{l}\text { June } 2020- \\
\text { June } 2022 \\
\text { (Not yet recruiting) }\end{array}$ & $\begin{array}{l}\text { NCT04353869 } \\
\text { Observational (N.A.) }\end{array}$ \\
\hline
\end{tabular}

Temozolomide was tested to observe the effects on SDH-mutant/deficient GISTs (NCT03556384). Temozolomide is an alkylating agent that has already been approved for use against glioblastoma multiforme and refractory anaplastic astrocytoma tumors. $S D H$-mutant/deficient GISTs show hypermethylation which leads to loss of proteins, specifically $\mathrm{O}^{6}$-methylguanine-DNA methyltransferase. The inhibition of this protein due to promotor methylation has shown to lead to effective use of alkylating agents in other cancer types [136]. The rationale was to use a known chemotherapy drug, temozolomide, against a type of tumor it had not been tested against. DNA methyltransferase inhibitor, Guadecitabine (SGI-110), was tested on wild type GISTs, pheochromocytoma, and paraganglioma associated with SDH deficiency in hereditary leiomyomatosis and renal cell carcinoma (NCT03165721). The rationale behind this studying is the methylation of SDH contributing to increased ROS and anaerobic environments causing cells to develop mutations. 
By inhibiting methylation, tumor growth and mutation can be slowed. Glutaminase inhibitor CB-839 was tested on SDH-deficient GISTs, SDH-deficient non-GIST tumors, triple-negative breast cancer, and others for their interactions with CB-839 and standard chemotherapy (NCT02071862). Glutamine metabolism has been shown to be upregulated in SDHB mutated cancers. Glutaminase-1 generates glutamate from glutamine which is then metabolized to $\alpha$-ketoglutarate by glutamate dehydrogenase [137]. The $\alpha$-ketoglutarate can then be used by the TCA cycle. This leads to an accumulation of succinate that stabilizes and activates HIF1 and HIF2 [138]. This reliance on glutamine metabolism by $S D H$ mutant cancers has created an increased sensitivity to glutaminase inhibitors. The rationale behind the trial is to introduce the glutaminase inhibitor to regular chemotherapy as a new way to slow tumor growth.

The synergy between nivolumab and cabozantinib is being tested in SDH and fumarate hydratase deficient renal cell carcinomas (NCT03635892). Nivolumab is a monoclonal antibody that inhibits programmed cell death-1 (PD-1). In SDH deficient tumors, PD-1 receptor-ligand signaling is dysregulated due to hypoxic conditions [139]. This combination therapy with the tyrosine kinase inhibitor, cabozantinib, will target both programmed cell death signaling and vascular endothelial growth factors [140].

$S D H$ mutation can lead to several different cancers including paragangliomas. However, there is little information on environmental and professional factors playing a role in cancer risk. This study is a cross-section of patients with the same sex, age, and gene affected without tumors. Environmental and professional conditions will be accessed and compared through an interview (NCT04481152).

Cancer-related SDH clinical trials look to target SDH mutation that leads to tumor progression. Many current therapies are ineffective against dysfunctional or mutated $S D H$ subtypes of their parent tumor class. By continuing these trials, cancer is being targeted through a mechanism that affects both tumor progression and maintenance. By inhibiting the mutant $S D H$ or restoring normal function, not only can tumor progression halt, but tumor recession can also take place.

Patient resistance to high altitude via their chemoreflex, a reflex associated with hyperventilation, was tested to find a link between altitude sickness and SDH functionality (NCT00202683). The rationale is that participants with an altered or pathogenic chemoreflex will be intolerant to high altitude and exhibit cerebral edema or pulmonary edema. While no results were published, the implications are that dysfunctional SDH subunits contribute to an inability of the carotid body to respond to changes in altitude. This now established relationship could inspire treatments with antioxidants or gene therapies.

The North American Mitochondrial Disease Consortium Patient Registry and Biorespiratory group aims to identify individuals with mitochondrial disorders and connect them with other current clinical trials for which they may be eligible. Additionally, patient tissue samples will also be cataloged and stored in a shared facility where several groups may have access to the samples to further their research (NCT01694940).

Macrophage mediated pro-inflammatory response is a common issue in diabetic and other related cardiovascular complications. Recent studies suggest that glutamine catabolism is involved in the activation of these macrophages through TCA cycle intermediates. The study will look at glutamine metabolism and levels of $\alpha$-ketoglutarate, fumarate, and succinate (NCT04353869).

Non-cancer related SDH trials cover a wide variety of diseases. SDH trials related to mitochondrial disease cover many different subsets related to genetic conditions. The chemoreflex also shows SDH in the capacity of internal respiration. This wide range of trials shows the dependency of the human body on $\mathrm{SDH}$.

\section{Future Directions}

In this study, we systematically summarized how the SDH complex interacts with the RNA networks to regulate the development of cancer and other diseases. There are several promising 
points that need to be investigated further in the future to better understand the mechanisms of SDH in pathogenesis.

First, it is of interest to study how SDH pseudogenes such as SDHAP1/2/3 interact with $\mathrm{SDHA} / \mathrm{B} / \mathrm{C} / \mathrm{D}$ subunits and other molecules. Utilizing the cutting-edge cryo-electron spectroscopy [141] will facilitate our understanding of this interaction and further insight on cancer and disease development. Unexpectedly, SDHAP1 is classified as a lncRNA in ovarian cancer [11]. It indicates that SDHAP1/2/3 might play a role independent of SDH-enzyme based metabolic reactions.

The studies of an interplay between SDH complex and non-coding RNAs are still at an early stage. Among them, only a limited number of miRNAs have been studied. A large-scale screening of non-coding RNAs using (small) RNA-sequencing should be applied to this study. Additionally, studies for RNA editors of SDH such as C-to-U editing by APOBEC1 and APOBEC3A have received increasing notices recently. In addition to this direct APOBEC1/3A-SDH interaction, RNA editors can also manipulate non-coding RNA levels in cancers and non-cancer diseases [142]. Thus, how RNA editors regulate SDH indirectly via editing non-coding RNAs needs to be investigated in the future. In turn, SDH inactivation-induced succinate accumulation can induce the upregulation of miRNAs such as miR-210. It is of interest to study whether succinate accumulation can also influence the activity of RNA editors. We need to highlight that the interaction of the SDH-RNA network is dynamic due to the fact that some RNAs can play roles as messengers because they may be transmitted from one type of cell to another type of cell. For example, cell-free circulating exosomal miRNAs can transmit signals when they are delivered from the original site to the target site [143]. Similar to circulating miRNAs, succinate has been discovered to shuttle from hypoxic retina to oxygen-enriched tissue to transfer electrons [144]. Thus, this new module provides a possibility that the SDH-RNA interaction can be applied in different microenvironments when RNA and succinate are transmitted remotely.

Severe fungal infections to humans have caused many deaths in patients [145]. Most of the fungicides are designed to combat human fungal pathogens through inhibiting cellular mitochondrial respiration such as SDH activities in fungi [146]. SDH inhibitors targeting fungus infection has been difficult to incorporate into human application due to the similar SDH structures in human and fungal cells. Thus, the following two concerns need to be addressed when applying the SDH inhibitors in antifungal (antipathogen) treatment in humans. The applied SDH inhibitors can be transmitted to human cells leading to increased risk of tumorigenesis due to inactivating tumor suppressor SDH in human cells. Additionally, some pathogens such as Gram-negative bacterial product lipopolysaccharide-induced succinate accumulation activate HIF- $1 \alpha$ and enhance the release of interleukin-1 $\beta$ in human macrophages [55]. Additionally, pathogen-derived succinate might also influence tumor initiation and progression in humans [116,147].

RNA-based therapeutics have received increasing attention recently due to its advantage of accuracy and specificity compared to conventional small molecules [148]. However, the delivery efficiency and off-target effect of RNA therapeutics need to be addressed properly before entering clinical trials. It is critical to improve the RNA delivery to targeted cells by using cutting-edge nanoparticles and ligand-conjugated carriers [149]. Simultaneously, exploring the distribution and functions of RNA-based-therapeutics in non-targeted cells (i.e., non-tumor cells in cancer) can facilitate the applications of RNA therapeutics entering clinical trials [150]. In the future, it is of importance to test the possibility of utilizing RNA-based therapeutics such as targeting non-coding RNAs, RNA editors, and RNA modifiers to conquer SDH mutation- or dysfunction-induced cancer and diseases.

Author Contributions: Conceptualization, C.M., R.M.S., R.B., and W.C.Z.; formal analysis, R.M.S., R.B., and C.M.; resources, C.M., R.M.S., and R.B.; data curation, C.M., R.M.S., and R.B.; writing-original draft preparation, R.M.S., C.M., R.B., and W.C.Z.; writing-review and editing, R.M.S., C.M., R.B., and W.C.Z.; visualization, C.M. (Figure 1), R.M.S. (Figures 2 and 3), R.B. (Figure 4 and Table 1), and R.M.S. (graphical abstract); supervision, W.C.Z.; project administration, W.C.Z; funding acquisition, W.C.Z. All authors have read and agreed to the published version of the manuscript. 
Funding: This research was funded by the Burnett School of Biomedical Sciences, College of Medicine, University of Central Florida grant 25400714 awarded to W.C.Z. Zhang's research is supported in part by a Young Investigator Award from the International Association for the Study of Lung Cancer and Atomwise Inc. (A19-053).

Acknowledgments: We thank Muthu Periasamy, Nicholas Skiados, and Jihoon Lim for critical reading and comments. We apologize to all researchers whose work could not be cited due to reference limitations. We thank the Office of Undergraduate Research and the Summer Undergraduate Research Fellowship at the University of Central Florida (awarded to Robert Burns). All figures were created with BioRender.com.

Conflicts of Interest: The authors declare no conflict of interest.

\section{Abbreviations}

ADARs Adenosine deaminases acting on RNA

ALKBH5 Alpha-ketoglutarate-dependent dioxygenase AlkB homolog 5

APOBEC Apolipoprotein B mRNA editing enzyme, catalytic polypeptide-like

APOBEC1 Apolipoprotein B mRNA editing enzyme catalytic subunit 1

APOBEC3A Apolipoprotein B mRNA editing enzyme catalytic subunit 3A

A-to-I Adenine to inosine

ATP Adenosine triphosphate

CRISPR Clustered regularly interspaced short palindromic repeats

C-to-U Cytidine to uracil

DCPIP 2,6-dichlorophenolindophenol

DNA Deoxyribonucleic acid

ETC Electron transport chain

FAD Flavin adenine dinucleotide

Fe-S Iron-Sulfur

FTO Fat mass and obesity-associated protein

GBM Glioblastoma multiforme

GISTs Gastrointestinal tumors

GPR91 G-protein coupled receptor 91

HIF-1 $\alpha \quad$ Hypoxia-inducible factor 1 alpha

HRLCC Hereditary leiomyomatosis and renal cell carcinoma

IL-1 $\beta \quad$ Interleukin 1 beta

IncRNA Long non-coding ribonucleic acid

mTOR Mammalian target of rapamycin

miRNA Micro-ribonucleic acid

$\mathrm{m}^{6} \mathrm{~A} \quad \mathrm{~N}^{6}$-methyladenosine

NAD Nicotinamide adenine dinucleotide

NADP+ Nicotinamide adenine dinucleotide phosphate

NADPH Nicotinamide adenine dinucleotide hydrogen

NBT Nitro blue tetrazolium

NRF1 Nuclear respiratory factor 1

PCC Pheochromocytoma

PGL Paraganglioma

PD-1 Programmed cell death-1

PHD HIF- $\alpha$ prolyl hydroxylase domain

PTEN Protein and tensin homolog

$\mathrm{Q}_{\mathrm{D}} \quad$ Distal binding site in ubiquinone

Qp Proximal binding site in ubiquinone

RNA Ribonucleic acid

ROS Reactive oxygen species

SIRT3 Sirtuin 3

SDH Succinate dehydrogenase

SDHA Succinate dehydrogenase subunit A

SDHAF1 Succinate dehydrogenase complex assembly factor 1

SDHAP1 Succinate dehydrogenase complex flavoprotein subunit a pseudogene 1 


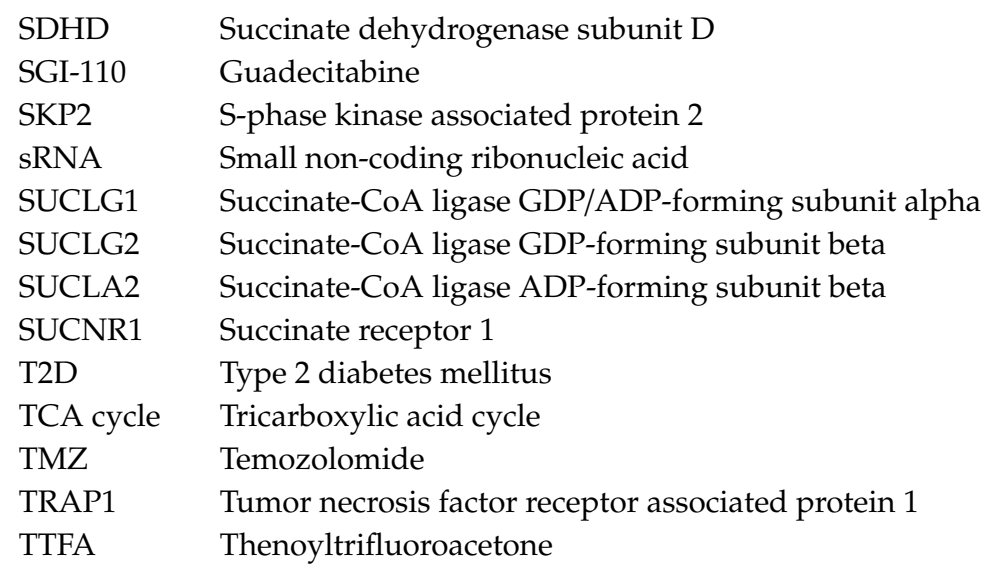

\section{References}

1. Rutter, J.; Winge, D.R.; Schiffman, J.D. Succinate dehydrogenase-Assembly, regulation and role in human disease. Mitochondrion 2010, 10, 393-401. [CrossRef]

2. Selak, M.A.; Armour, S.M.; MacKenzie, E.D.; Boulahbel, H.; Watson, D.G.; Mansfield, K.D.; Pan, Y.; Simon, M.C.; Thompson, C.B.; Gottlieb, E. Succinate links TCA cycle dysfunction to oncogenesis by inhibiting HIF-alpha prolyl hydroxylase. Cancer Cell 2005, 7, 77-85. [CrossRef] [PubMed]

3. Barbieri, I.; Kouzarides, T. Role of RNA modifications in cancer. Nat. Rev. Cancer 2020, 20, 303-322. [CrossRef] [PubMed]

4. Slack, F.J.; Chinnaiyan, A.M. The Role of Non-coding RNAs in Oncology. Cell 2019, 179, 1033-1055. [CrossRef] [PubMed]

5. Puissegur, M.P.; Mazure, N.M.; Bertero, T.; Pradelli, L.; Grosso, S.; Robbe-Sermesant, K.; Maurin, T.; Lebrigand, K.; Cardinaud, B.; Hofman, V.; et al. miR-210 is overexpressed in late stages of lung cancer and mediates mitochondrial alterations associated with modulation of HIF-1 activity. Cell Death Differ. 2011, 18, 465-478. [CrossRef] [PubMed]

6. Zhang, W.C.; Wells, J.M.; Chow, K.H.; Huang, H.; Yuan, M.; Saxena, T.; Melnick, M.A.; Politi, K.; Asara, J.M.; Costa, D.B.; et al. miR-147b-mediated TCA cycle dysfunction and pseudohypoxia initiate drug tolerance to EGFR inhibitors in lung adenocarcinoma. Nat. Metab. 2019, 1, 460-474. [CrossRef] [PubMed]

7. Pinto, Y.; Buchumenski, I.; Levanon, E.Y.; Eisenberg, E. Human cancer tissues exhibit reduced A-to-I editing of miRNAs coupled with elevated editing of their targets. Nucleic Acids Res. 2018, 46, 71-82. [CrossRef] [PubMed]

8. Alarcon, C.R.; Lee, H.; Goodarzi, H.; Halberg, N.; Tavazoie, S.F. N6-methyladenosine marks primary microRNAs for processing. Nature 2015, 519, 482-485. [CrossRef]

9. Sharma, P.; Maklashina, E.; Cecchini, G.; Iverson, T.M. The roles of SDHAF2 and dicarboxylate in covalent flavinylation of SDHA, the human complex II flavoprotein. Proc. Natl. Acad. Sci. USA 2020. [CrossRef] [PubMed]

10. Maio, N.; Ghezzi, D.; Verrigni, D.; Rizza, T.; Bertini, E.; Martinelli, D.; Zeviani, M.; Singh, A.; Carrozzo, R.; Rouault, T.A. Disease-Causing SDHAF1 Mutations Impair Transfer of Fe-S Clusters to SDHB. Cell Metab. 2016, 23, 292-302. [CrossRef]

11. Zhao, H.; Wang, A.; Zhang, Z. LncRNA SDHAP1 confers paclitaxel resistance of ovarian cancer by regulating EIF4G2 expression via miR-4465. J. Biochem. 2020, 168, 171-181. [CrossRef]

12. Hu, X.; Yang, L.; Mo, Y.-Y. Role of Pseudogenes in Tumorigenesis. Cancers 2018, 10, 256. [CrossRef]

13. Kim, H.J.; Winge, D.R. Emerging concepts in the flavinylation of succinate dehydrogenase. Biochim. Biophys. Acta 2013, 1827, 627-636. [CrossRef]

14. Van Vranken, J.G.; Bricker, D.K.; Dephoure, N.; Gygi, S.P.; Cox, J.E.; Thummel, C.S.; Rutter, J. SDHAF4 promotes mitochondrial succinate dehydrogenase activity and prevents neurodegeneration. Cell Metab. 2014, 20, 241-252. [CrossRef] [PubMed]

15. Delatycki, M.B.; Williamson, R.; Forrest, S.M. Friedreich ataxia: An overview. J. Med. Genet. 2000, 37, 1-8. [CrossRef] 
16. Stehling, O.; Elsässer, H.-P.; Brückel, B.; Mühlenhoff, U.; Lill, R. Iron-sulfur protein maturation in human cells: Evidence for a function of frataxin. Hum. Mol. Genet. 2004, 13, 3007-3015. [CrossRef] [PubMed]

17. Na, U.; Yu, W.; Cox, J.; Bricker, D.K.; Brockmann, K.; Rutter, J.; Thummel, C.S.; Winge, D.R. The LYR factors SDHAF1 and SDHAF3 mediate maturation of the iron-sulfur subunit of succinate dehydrogenase. Cell Metab. 2014, 20, 253-266. [CrossRef]

18. Oyedotun, K.S.; Sit, C.S.; Lemire, B.D. The Saccharomyces cerevisiae succinate dehydrogenase does not require heme for ubiquinone reduction. Biochim. Biophys. Acta (BBA) Bioenerg. 2007, 1767, 1436-1445. [CrossRef]

19. Sun, F.; Huo, X.; Zhai, Y.; Wang, A.; Xu, J.; Su, D.; Bartlam, M.; Rao, Z. Crystal Structure of Mitochondrial Respiratory Membrane Protein Complex II. Cell 2005, 121, 1043-1057. [CrossRef]

20. Enriquez, J.A.; Lenaz, G. Coenzyme q and the respiratory chain: Coenzyme q pool and mitochondrial supercomplexes. Mol. Syndromol. 2014, 5, 119-140. [CrossRef] [PubMed]

21. Van Vranken, J.G.; Na, U.; Winge, D.R.; Rutter, J. Protein-mediated assembly of succinate dehydrogenase and its cofactors. Crit. Rev. Biochem. Mol. Biol. 2015, 50, 168-180. [CrossRef]

22. Guzy, R.D.; Sharma, B.; Bell, E.; Chandel, N.S.; Schumacker, P.T. Loss of the SdhB, but Not the SdhA, subunit of complex II triggers reactive oxygen species-dependent hypoxia-inducible factor activation and tumorigenesis. Mol. Cell. Biol. 2008, 28, 718-731. [CrossRef]

23. Ishii, T.; Yasuda, K.; Akatsuka, A.; Hino, O.; Hartman, P.S.; Ishii, N. A mutation in the SDHC gene of complex II increases oxidative stress, resulting in apoptosis and tumorigenesis. Cancer Res. 2005, 65, 203-209.

24. Slane, B.G.; Aykin-Burns, N.; Smith, B.J.; Kalen, A.L.; Goswami, P.C.; Domann, F.E.; Spitz, D.R. Mutation of succinate dehydrogenase subunit $\mathrm{C}$ results in increased $\mathrm{O} 2 .-$, oxidative stress, and genomic instability. Cancer Res. 2006, 66, 7615-7620. [CrossRef]

25. Zimna, A.; Kurpisz, M. Hypoxia-Inducible Factor-1 in Physiological and Pathophysiological Angiogenesis: Applications and Therapies. BioMed Res. Int. 2015, 2015, 549412. [CrossRef]

26. Smith, E.H.; Janknecht, R.; Maher, L.J., III. Succinate inhibition of $\alpha$-ketoglutarate-dependent enzymes in a yeast model of paraganglioma. Hum. Mol. Genet. 2007, 16, 3136-3148. [CrossRef]

27. Zhang, Y.; Zhang, M.; Zhu, W.; Yu, J.; Wang, Q.; Zhang, J.; Cui, Y.; Pan, X.; Gao, X.; Sun, H. Succinate accumulation induces mitochondrial reactive oxygen species generation and promotes status epilepticus in the kainic acid rat model. Redox Biol. 2020, 28, 101365. [CrossRef] [PubMed]

28. Letouzé, E.; Martinelli, C.; Loriot, C.; Burnichon, N.; Abermil, N.; Ottolenghi, C.; Janin, M.; Menara, M.; Nguyen, A.T.; Benit, P.; et al. SDH Mutations Establish a Hypermethylator Phenotype in Paraganglioma. Cancer Cell 2013, 23, 739-752. [CrossRef]

29. Astuti, D.; Latif, F.; Dallol, A.; Dahia, P.L.M.; Douglas, F.; George, E.; Sköldberg, F.; Husebye, E.S.; Eng, C.; Maher, E.R. Gene Mutations in the Succinate Dehydrogenase Subunit SDHB Cause Susceptibility to Familial Pheochromocytoma and to Familial Paraganglioma. Am. J. Hum. Genet. 2001, 69, 49-54. [CrossRef]

30. Niemann, S.; Müller, U. Mutations in SDHC cause autosomal dominant paraganglioma, type 3. Nat. Genet. 2000, 26, 268-270. [CrossRef] [PubMed]

31. Baysal, B.E.; Ferrell, R.E.; Willett-Brozick, J.E.; Lawrence, E.C.; Myssiorek, D.; Bosch, A.; van der Mey, A.; Taschner, P.E.; Rubinstein, W.S.; Myers, E.N.; et al. Mutations in SDHD, a mitochondrial complex II gene, in hereditary paraganglioma. Science 2000, 287, 848-851. [CrossRef] [PubMed]

32. Bardella, C.; Pollard, P.J.; Tomlinson, I. SDH mutations in cancer. Biochim. Biophys. Acta (BBA) Bioenerg. 2011, 1807, 1432-1443. [CrossRef]

33. Wojtovich, A.P.; Foster, T.H. Optogenetic control of ROS production. Redox Biol. 2014, 2, 368-376. [CrossRef] [PubMed]

34. Gimenez-Roqueplo, A.-P.; Favier, J.; Rustin, P.; Mourad, J.-J.; Plouin, P.-F.; Corvol, P.; Rötig, A.; Jeunemaitre, X. The R22X Mutation of the SDHD Gene in Hereditary Paraganglioma Abolishes the Enzymatic Activity of Complex II in the Mitochondrial Respiratory Chain and Activates the Hypoxia Pathway. Am. J. Hum. Genet. 2001, 69, 1186-1197. [CrossRef]

35. Pasini, B.; Stratakis, C.A. SDH mutations in tumorigenesis and inherited endocrine tumours: Lesson from the phaeochromocytoma-paraganglioma syndromes. J. Int. Med. 2009, 266, 19-42. [CrossRef]

36. Bayley, J.P.; Kunst, H.P.; Cascon, A.; Sampietro, M.L.; Gaal, J.; Korpershoek, E.; Hinojar-Gutierrez, A.; Timmers, H.J.; Hoefsloot, L.H.; Hermsen, M.A.; et al. SDHAF2 mutations in familial and sporadic paraganglioma and phaeochromocytoma. Lancet Oncol. 2010, 11, 366-372. [CrossRef] 
37. Fishbein, L.; Nathanson, K.L. Pheochromocytoma and paraganglioma: Understanding the complexities of the genetic background. Cancer Genet. 2012, 205, 1-11. [CrossRef]

38. Chen, L.; Liu, T.; Zhang, S.; Zhou, J.; Wang, Y.; Di, W. Succinate dehydrogenase subunit B inhibits the AMPK-HIF-1 $\alpha$ pathway in human ovarian cancer in vitro. J. Ovarian Res. 2014, 7, 115. [CrossRef]

39. Tseng, P.-L.; Wu, W.-H.; Hu, T.-H.; Chen, C.-W.; Cheng, H.-C.; Li, C.-F.; Tsai, W.-H.; Tsai, H.-J.; Hsieh, M.-C.; Chuang, J.-H.; et al. Decreased succinate dehydrogenase B in human hepatocellular carcinoma accelerates tumor malignancy by inducing the Warburg effect. Sci. Rep. 2018, 8, 3081. [CrossRef] [PubMed]

40. Zhang, D.; Wang, W.; Xiang, B.; Li, N.; Huang, S.; Zhou, W.; Sun, Y.; Wang, X.; Ma, J.; Li, G.; et al. Reduced succinate dehydrogenase $\mathrm{B}$ expression is associated with growth and de-differentiation of colorectal cancer cells. Tumor Biol. 2013, 34, 2337-2347. [CrossRef]

41. Janeway, K.A.; Kim, S.Y.; Lodish, M.; Nosé, V.; Rustin, P.; Gaal, J.; Dahia, P.L.M.; Liegl, B.; Ball, E.R.; Raygada, M.; et al. Defects in succinate dehydrogenase in gastrointestinal stromal tumors lacking KIT and PDGFRA mutations. Proc. Natl. Acad. Sci. USA 2011, 108, 314-318. [CrossRef]

42. Nannini, M.; Urbini, M.; Indio, V.; Schipani, A.; Vincenzi, B.; Silletta, M.; Grignani, G.; Tolomeo, F.; Rizzo, A.; Fumagalli, E.; et al. Identification of SDHA germline mutations in sporadic SDHA mutant gastrointestinal stromal tumors (GIST): The need of a genetic counselling. J. Clin. Oncol. 2020, 38, 11537. [CrossRef]

43. Flavahan, W.A.; Drier, Y.; Johnstone, S.E.; Hemming, M.L.; Tarjan, D.R.; Hegazi, E.; Shareef, S.J.; Javed, N.M.; Raut, C.P.; Eschle, B.K.; et al. Altered chromosomal topology drives oncogenic programs in SDH-deficient GISTs. Nature 2019, 575, 229-233. [CrossRef]

44. Ricketts, C.J.; Forman, J.R.; Rattenberry, E.; Bradshaw, N.; Lalloo, F.; Izatt, L.; Cole, T.R.; Armstrong, R.; Kumar, V.K.; Morrison, P.J.; et al. Tumor risks and genotype-phenotype-proteotype analysis in 358 patients with germline mutations in SDHB and SDHD. Hum. Mutat. 2010, 31, 41-51. [CrossRef]

45. Xekouki, P.; Szarek, E.; Bullova, P.; Giubellino, A.; Quezado, M.; Mastroyannis, S.A.; Mastorakos, P.; Wassif, C.A.; Raygada, M.; Rentia, N.; et al. Pituitary Adenoma With Paraganglioma/Pheochromocytoma (3PAs) and Succinate Dehydrogenase Defects in Humans and Mice. J. Clin. Endocrinol. Metab. 2015, 100, E710-E719. [CrossRef]

46. Roh, T.H.; Yim, H.; Roh, J.; Lee, K.B.; Park, S.H.; Jeong, S.-Y.; Kim, S.-H.; Kim, J.-H. The loss of succinate dehydrogenase B expression is frequently identified in hemangioblastoma of the central nervous system. Sci. Rep. 2019, 9, 5873. [CrossRef]

47. Luks, A.M.; Swenson, E.R.; Bärtsch, P. Acute high-altitude sickness. Eur. Respir. Rev. 2017, 26. [CrossRef]

48. Murray, A.J.; Horscroft, J.A. Mitochondrial function at extreme high altitude. J. Physiol. 2016, 594, 1137-1149. [CrossRef]

49. Bakonyi, T.; Radak, Z. High altitude and free radicals. J. Sports Sci. Med. 2004, 3, 64-69.

50. Guzy, R.D.; Schumacker, P.T. Oxygen sensing by mitochondria at complex III: The paradox of increased reactive oxygen species during hypoxia. Exp. Physiol. 2006, 91, 807-819. [CrossRef]

51. Lu, H.; Wang, R.; Li, W.; Xie, H.; Wang, C.; Hao, Y.; Sun, Y.; Jia, Z. Plasma proteomic study of acute mountain sickness susceptible and resistant individuals. Sci. Rep. 2018, 8, 1265. [CrossRef]

52. Landsverk, M.L.; Zhang, V.W.; Wong, L.-J.C.; Andersson, H.C. A SUCLG1 mutation in a patient with mitochondrial DNA depletion and congenital anomalies. Mol. Genet. Metab. Rep. 2014, 1, 451-454. [CrossRef]

53. Chinopoulos, C.; Batzios, S.; van den Heuvel, L.P.; Rodenburg, R.; Smeets, R.; Waterham, H.R.; Turkenburg, M.; Ruiter, J.P.; Wanders, R.J.A.; Doczi, J.; et al. Mutated SUCLG1 causes mislocalization of SUCLG2 protein, morphological alterations of mitochondria and an early-onset severe neurometabolic disorder. Mol. Genet. Metab. 2019, 126, 43-52. [CrossRef]

54. Cerecer-Gil, N.Y.; Figuera, L.E.; Llamas, F.J.; Lara, M.; Escamilla, J.G.; Ramos, R.; Estrada, G.; Hussain, A.K.; Gaal, J.; Korpershoek, E.; et al. Mutation of $S D H B$ is a Cause of Hypoxia-Related High-Altitude Paraganglioma. Clin. Cancer Res. 2010, 16, 4148-4154. [CrossRef]

55. Tannahill, G.M.; Curtis, A.M.; Adamik, J.; Palsson-McDermott, E.M.; McGettrick, A.F.; Goel, G.; Frezza, C.; Bernard, N.J.; Kelly, B.; Foley, N.H.; et al. Succinate is an inflammatory signal that induces IL-1beta through HIF-1alpha. Nature 2013, 496, 238-242. [CrossRef]

56. Mills, E.L.; Kelly, B.; Logan, A.; Costa, A.S.H.; Varma, M.; Bryant, C.E.; Tourlomousis, P.; Däbritz, J.H.M.; Gottlieb, E.; Latorre, I.; et al. Succinate Dehydrogenase Supports Metabolic Repurposing of Mitochondria to Drive Inflammatory Macrophages. Cell 2016, 167, 457-470.e413. [CrossRef] 
57. Littlewood-Evans, A.; Sarret, S.; Apfel, V.; Loesle, P.; Dawson, J.; Zhang, J.; Muller, A.; Tigani, B.; Kneuer, R.; Patel, S.; et al. GPR91 senses extracellular succinate released from inflammatory macrophages and exacerbates rheumatoid arthritis. J. Exp. Med. 2016, 213, 1655-1662. [CrossRef]

58. Peruzzotti-Jametti, L.; Bernstock, J.D.; Vicario, N.; Costa, A.S.H.; Kwok, C.K.; Leonardi, T.; Booty, L.M.; Bicci, I.; Balzarotti, B.; Volpe, G.; et al. Macrophage-Derived Extracellular Succinate Licenses Neural Stem Cells to Suppress Chronic Neuroinflammation. Cell Stem Cell 2018, 22, 355-368.e313. [CrossRef]

59. Zhang, Y.; Liu, J.; Chen, X.Q.; Oliver Chen, C.Y. Ubiquinol is superior to ubiquinone to enhance Coenzyme Q10 status in older men. Food Funct. 2018, 9, 5653-5659. [CrossRef]

60. Rustin, P.; Munnich, A.; Rötig, A. Succinate dehydrogenase and human diseases: New insights into a well-known enzyme. Eur. J. Hum. Genet. 2002, 10, 289-291. [CrossRef]

61. Zhu, Z.; Yao, J.; Johns, T.; Fu, K.; Bie, I.D.; Macmillan, C.; Cuthbert, A.P.; Newbold, R.F.; Wang, J.-C.; Chevrette, M.; et al. SURF1, encoding a factor involved in the biogenesis of cytochrome c oxidase, is mutated in Leigh syndrome. Nat. Genet. 1998, 20, 337-343. [CrossRef]

62. Parfait, B.; Chretien, D.; Rötig, A.; Marsac, C.; Munnich, A.; Rustin, P. Compound heterozygous mutations in the flavoprotein gene of the respiratory chain complex II in a patient with Leigh syndrome. Hum. Genet. 2000, 106, 236-243. [CrossRef]

63. Birch-Machin, M.A.; Taylor, R.W.; Cochran, B.; Ackrell, B.A.; Turnbull, D.M. Late-onset optic atrophy, ataxia, and myopathy associated with a mutation of a complex II gene. Ann. Neurol. 2000, 48, 330-335. [CrossRef]

64. Alston, C.L.; Davison, J.E.; Meloni, F.; van der Westhuizen, F.H.; He, L.; Hornig-Do, H.T.; Peet, A.C.; Gissen, P.; Goffrini, P.; Ferrero, I.; et al. Recessive germline SDHA and SDHB mutations causing leukodystrophy and isolated mitochondrial complex II deficiency. J. Med. Genet. 2012, 49, 569-577. [CrossRef]

65. Jackson, C.B.; Nuoffer, J.-M.; Hahn, D.; Prokisch, H.; Haberberger, B.; Gautschi, M.; Häberli, A.; Gallati, S.; Schaller, A. Mutations in SDHD lead to autosomal recessive encephalomyopathy and isolated mitochondrial complex II deficiency. J. Med. Genet. 2014, 51, 170-175. [CrossRef] [PubMed]

66. Ghezzi, D.; Goffrini, P.; Uziel, G.; Horvath, R.; Klopstock, T.; Lochmüller, H.; D’Adamo, P.; Gasparini, P.; Strom, T.M.; Prokisch, H.; et al. SDHAF1, encoding a LYR complex-II specific assembly factor, is mutated in SDH-defective infantile leukoencephalopathy. Nat. Genet. 2009, 41, 654-656. [CrossRef] [PubMed]

67. Farshbaf, M.J.; Kiani-Esfahani, A. Succinate dehydrogenase: Prospect for neurodegenerative diseases. Mitochondrion 2018, 42, 77-83. [CrossRef]

68. Villa-Cuesta, E.; Holmbeck, M.A.; Rand, D.M. Rapamycin increases mitochondrial efficiency by mtDNA-dependent reprogramming of mitochondrial metabolism in Drosophila. J. Cell Sci. 2014, 127, 2282-2290. [CrossRef] [PubMed]

69. Jahrling, J.B.; Laberge, R.-M. Age-Related Neurodegeneration Prevention Through mTOR Inhibition: Potential Mechanisms and Remaining Questions. Curr. Top. Med. Chem. 2015, 15, 2139-2151. [CrossRef]

70. Fahien, L.A.; MacDonald, M.J. The succinate mechanism of insulin release. Diabetes 2002, 51, $2669-2676$. [CrossRef]

71. Haythorne, E.; Rohm, M.; van de Bunt, M.; Brereton, M.F.; Tarasov, A.I.; Blacker, T.S.; Sachse, G.; dos Santos, M.S.; Exposito, R.T.; Davis, S.; et al. Diabetes causes marked inhibition of mitochondrial metabolism in pancreatic $\beta$-cells. Nat. Commun. 2019, 10, 2474. [CrossRef]

72. Sadagopan, N.; Li, W.; Roberds, S.L.; Major, T.; Preston, G.M.; Yu, Y.; Tones, M.A. Circulating succinate is elevated in rodent models of hypertension and metabolic disease. Am. J. Hypertens. 2007, 20, 1209-1215. [CrossRef]

73. Toma, I.; Kang, J.J.; Sipos, A.; Vargas, S.; Bansal, E.; Hanner, F.; Meer, E.; Peti-Peterdi, J. Succinate receptor GPR91 provides a direct link between high glucose levels and renin release in murine and rabbit kidney. $J$. Clin. Investig. 2008, 118, 2526-2534. [CrossRef]

74. Gurley, S.B.; Coffman, T.M. The Renin-Angiotensin System and Diabetic Nephropathy. Semin. Nephrol. 2007, 27, 144-152. [CrossRef]

75. Chouchani, E.T.; Pell, V.R.; Gaude, E.; Aksentijević, D.; Sundier, S.Y.; Robb, E.L.; Logan, A.; Nadtochiy, S.M.; Ord, E.N.J.; Smith, A.C.; et al. Ischaemic accumulation of succinate controls reperfusion injury through mitochondrial ROS. Nature 2014, 515, 431-435. [CrossRef]

76. Zhang, J.; Wang, Y.T.; Miller, J.H.; Day, M.M.; Munger, J.C.; Brookes, P.S. Accumulation of Succinate in Cardiac Ischemia Primarily Occurs via Canonical Krebs Cycle Activity. Cell Rep. 2018, 23, 2617-2628. [CrossRef] 
77. Dudek, J.; Cheng, I.F.; Chowdhury, A.; Wozny, K.; Balleininger, M.; Reinhold, R.; Grunau, S.; Callegari, S.; Toischer, K.; Wanders, R.J.; et al. Cardiac-specific succinate dehydrogenase deficiency in Barth syndrome. EMBO Mol. Med. 2016, 8, 139-154. [CrossRef] [PubMed]

78. Kaikkonen, M.U.; Lam, M.T.Y.; Glass, C.K. Non-coding RNAs as regulators of gene expression and epigenetics. Cardiovasc. Res. 2011, 90, 430-440. [CrossRef]

79. Esteller, M. Non-coding RNAs in human disease. Nat. Rev. Genet. 2011, 12, 861-874. [CrossRef]

80. Santos, R.M.; Moreno, C.; Zhang, W.C. Non-Coding RNAs in Lung Tumor Initiation and Progression. Int. J. Mol. Sci. 2020, 21, 2774. [CrossRef]

81. Anastasiadou, E.; Jacob, L.S.; Slack, F.J. Non-coding RNA networks in cancer. Nat. Rev. Cancer 2018, 18, 5-18. [CrossRef]

82. Tan, L.; Yu, J.T.; Hu, N.; Tan, L. Non-coding RNAs in Alzheimer's disease. Mol. Neurobiol. 2013, 47, $382-393$. [CrossRef]

83. Lee, M.R.; Mantel, C.; Lee, S.A.; Moon, S.-H.; Broxmeyer, H.E. MiR-31/SDHA Axis Regulates Reprogramming Efficiency through Mitochondrial Metabolism. Stem Cell Rep. 2016, 7, 1-10. [CrossRef]

84. Wang, X.; Wang, X. Systematic identification of microRNA functions by combining target prediction and expression profiling. Nucleic Acids Res. 2006, 34, 1646-1652. [CrossRef]

85. Metruccio, M.M.E.; Fantappiè, L.; Serruto, D.; Muzzi, A.; Roncarati, D.; Donati, C.; Scarlato, V.; Delany, I. The Hfq-Dependent Small Noncoding RNA NrrF Directly Mediates Fur-Dependent Positive Regulation of Succinate Dehydrogenase in Neisseria meningitidis. J. Bacteriol. 2009, 191, 1330-1342. [CrossRef]

86. Sirey, T.M.; Roberts, K.; Haerty, W.; Bedoya-Reina, O.; Rogatti-Granados, S.; Tan, J.Y.; Li, N.; Heather, L.C.; Carter, R.N.; Cooper, S.; et al. The long non-coding RNA Cerox1 is a post transcriptional regulator of mitochondrial complex I catalytic activity. eLife 2019, 8. [CrossRef]

87. Simpson, L.; Emeson, R.B. RNA editing. Annu. Rev. Neurosci. 1996, 19, 27-52. [CrossRef]

88. Nishikura, K. Functions and regulation of RNA editing by ADAR deaminases. Annu. Rev. Biochem. 2010, 79, 321-349. [CrossRef]

89. Zhang, W.C.; Slack, F.J. ADARs Edit MicroRNAs to Promote Leukemic Stem Cell Activity. Cell Stem Cell 2016, 19, 141-142. [CrossRef]

90. Salter, J.D.; Bennett, R.P.; Smith, H.C. The APOBEC Protein Family: United by Structure, Divergent in Function. Trends Biochem. Sci. 2016, 41, 578-594. [CrossRef]

91. Baysal, B.E.; De Jong, K.; Liu, B.; Wang, J.; Patnaik, S.K.; Wallace, P.K.; Taggart, R.T. Hypoxia-inducible C-to-U coding RNA editing downregulates SDHB in monocytes. PeerJ 2013, 1, e152. [CrossRef]

92. Sharma, S.; Patnaik, S.K.; Taggart, R.T.; Kannisto, E.D.; Enriquez, S.M.; Gollnick, P.; Baysal, B.E. APOBEC3A cytidine deaminase induces RNA editing in monocytes and macrophages. Nat. Commun. 2015, 6, 6881. [CrossRef]

93. Kawahara, Y.; Zinshteyn, B.; Sethupathy, P.; Iizasa, H.; Hatzigeorgiou, A.G.; Nishikura, K. Redirection of silencing targets by adenosine-to-inosine editing of miRNAs. Science 2007, 315, 1137-1140. [CrossRef] [PubMed]

94. Choe, J.; Lin, S.; Zhang, W.; Liu, Q.; Wang, L.; Ramirez-Moya, J.; Du, P.; Kim, W.; Tang, S.; Sliz, P.; et al. mRNA circularization by METTL3-eIF3h enhances translation and promotes oncogenesis. Nature 2018, 561, 556-560. [CrossRef]

95. Shi, H.; Wei, J.; He, C. Where, When, and How: Context-Dependent Functions of RNA Methylation Writers, Readers, and Erasers. Mol. Cell. 2019, 74, 640-650. [CrossRef]

96. Kaelin, W.G., Jr. Cancer and altered metabolism: Potential importance of hypoxia-inducible factor and 2-oxoglutarate-dependent dioxygenases. Cold Spring Harb. Symp. Quant. Biol. 2011, 76, 335-345. [CrossRef]

97. Ma, S.; Chen, C.; Ji, X.; Liu, J.; Zhou, Q.; Wang, G.; Yuan, W.; Kan, Q.; Sun, Z. The interplay between m6A RNA methylation and noncoding RNA in cancer. J. Hematol. Oncol. 2019, 12, 121. [CrossRef] [PubMed]

98. Zheng, G.; Dahl, J.A.; Niu, Y.; Fedorcsak, P.; Huang, C.-M.; Li, C.J.; Vågbø, C.B.; Shi, Y.; Wang, W.-L.; Song, S.-H.; et al. ALKBH5 is a mammalian RNA demethylase that impacts RNA metabolism and mouse fertility. Mol. Cell. 2013, 49, 18-29. [CrossRef]

99. Latchman, D.S. Transcription factors: An overview. Int. J. Exp. Pathol. 1993, 74, 417-422. [CrossRef]

100. Lee, T.I.; Young, R.A. Transcriptional regulation and its misregulation in disease. Cell 2013, 152, $1237-1251$. [CrossRef] 
101. Piantadosi, C.A.; Suliman, H.B. Transcriptional Regulation of SDHa flavoprotein by nuclear respiratory factor-1 prevents pseudo-hypoxia in aerobic cardiac cells. J. Biol. Chem. 2008, 283, 10967-10977. [CrossRef] [PubMed]

102. Li, S.-T.; Huang, D.; Shen, S.; Cai, Y.; Xing, S.; Wu, G.; Jiang, Z.; Hao, Y.; Yuan, M.; Wang, N.; et al. Myc-mediated SDHA acetylation triggers epigenetic regulation of gene expression and tumorigenesis. Nat. Metab. 2020, 2, 256-269. [CrossRef] [PubMed]

103. Wang, Y.; Liu, J.; Huang, B.O.; Xu, Y.-M.; Li, J.; Huang, L.-F.; Lin, J.; Zhang, J.; Min, Q.-H.; Yang, W.-M.; et al. Mechanism of alternative splicing and its regulation. Biomed. Rep. 2015, 3, 152-158. [CrossRef]

104. Satoh, N.; Yokoyama, C.; Itamura, N.; Miyajima-Nakano, Y.; Hisatomi, H. Alternative splicing isoform in succinate dehydrogenase complex, subunit $\mathrm{C}$ causes downregulation of succinate-coenzyme $\mathrm{Q}$ oxidoreductase activity in mitochondria. Oncol. Lett. 2015, 9, 330-334. [CrossRef] [PubMed]

105. Maklashina, E.; Cecchini, G. The quinone-binding and catalytic site of complex II. Biochim. Biophys. Acta 2010, 1797, 1877-1882. [CrossRef]

106. Hagerhall, C. Succinate: Quinone oxidoreductases. Variations on a conserved theme. Biochim. Biophys. Acta 1997, 1320, 107-141. [CrossRef]

107. Tappel, A.L. Inhibition of electron transport by antimycin A, alkyl hydroxy naphthoquinones and metal coordination compounds. Biochem. Pharmacol. 1960, 3, 289-296. [CrossRef]

108. Yao, T.T.; Fang, S.W.; Li, Z.S.; Xiao, D.X.; Cheng, J.L.; Ying, H.Z.; Du, Y.J.; Zhao, J.H.; Dong, X.W. Discovery of Novel Succinate Dehydrogenase Inhibitors by the Integration of in Silico Library Design and Pharmacophore Mapping. J. Agric. Food Chem. 2017, 65, 3204-3211. [CrossRef]

109. Eprintsev, A.T.; Fedorin, D.N.; Karabutova, L.A.; Pokusina, T.A. Light regulation of succinate dehydrogenase subunit B gene SDH2-3 expression in maize leaves. Russ. J. Plant Physiol. 2016, 63, 505-510. [CrossRef]

110. Kruspig, B.; Valter, K.; Skender, B.; Zhivotovsky, B.; Gogvadze, V. Targeting succinate:ubiquinone reductase potentiates the efficacy of anticancer therapy. Biochim. Biophys. Acta 2016, 1863, 2065-2071. [CrossRef]

111. Dong, L.F.; Low, P.; Dyason, J.C.; Wang, X.F.; Prochazka, L.; Witting, P.K.; Freeman, R.; Swettenham, E.; Valis, K.; Liu, J.; et al. Alpha-tocopheryl succinate induces apoptosis by targeting ubiquinone-binding sites in mitochondrial respiratory complex II. Oncogene 2008, 27, 4324-4335. [CrossRef]

112. Valls-Lacalle, L.; Barba, I.; Miró-Casas, E.; Ruiz-Meana, M.; Rodríguez-Sinovas, A.; García-Dorado, D. Selective Inhibition of Succinate Dehydrogenase in Reperfused Myocardium with Intracoronary Malonate Reduces Infarct Size. Sci. Rep. 2018, 8, 2442. [CrossRef] [PubMed]

113. Stepanova, A.; Shurubor, Y.; Valsecchi, F.; Manfredi, G.; Galkin, A. Differential susceptibility of mitochondrial complex II to inhibition by oxaloacetate in brain and heart. Biochim. Biophys. Acta 2016, 1857, 1561-1568. [CrossRef]

114. Sciacovelli, M.; Guzzo, G.; Morello, V.; Frezza, C.; Zheng, L.; Nannini, N.; Calabrese, F.; Laudiero, G.; Esposito, F.; Landriscina, M.; et al. The Mitochondrial Chaperone TRAP1 Promotes Neoplastic Growth by Inhibiting Succinate Dehydrogenase. Cell Metab. 2013, 17, 988-999. [CrossRef] [PubMed]

115. Guzzo, G.; Sciacovelli, M.; Bernardi, P.; Rasola, A. Inhibition of succinate dehydrogenase by the mitochondrial chaperone TRAP1 has anti-oxidant and anti-apoptotic effects on tumor cells. Oncotarget 2014, 5, 11897-11908. [CrossRef]

116. Tretter, L.; Patocs, A.; Chinopoulos, C. Succinate, an intermediate in metabolism, signal transduction, ROS, hypoxia, and tumorigenesis. Biochim. Biophys. Acta 2016, 1857, 1086-1101. [CrossRef]

117. Fan, F.; Sam, R.; Ryan, E.; Alvarado, K.; Villa-Cuesta, E. Rapamycin as a potential treatment for succinate dehydrogenase deficiency. Heliyon 2019, 5, e01217. [CrossRef] [PubMed]

118. Kumar, A.; Prakash, A.; Dogra, S. Naringin alleviates cognitive impairment, mitochondrial dysfunction and oxidative stress induced by d-galactose in mice. Food Chem. Toxicol. 2010, 48, 626-632. [CrossRef]

119. Cimen, H.; Han, M.J.; Yang, Y.; Tong, Q.; Koc, H.; Koc, E.C. Regulation of succinate dehydrogenase activity by SIRT3 in mammalian mitochondria. Biochemistry 2010, 49, 304-311. [CrossRef]

120. Finley, L.W.; Haigis, M.C. Metabolic regulation by SIRT3: Implications for tumorigenesis. Trends Mol. Med. 2012, 18, 516-523. [CrossRef]

121. Eprintsev, A.T.; Fedorin, D.N.; Dobychina, M.A.; Igamberdiev, A.U. Expression and promoter methylation of succinate dehydrogenase and fumarase genes in maize under anoxic conditions. J. Plant Physiol. 2017, 216, 197-201. [CrossRef] [PubMed] 
122. Foster, A.J.; Martin-Urdiroz, M.; Yan, X.; Wright, H.S.; Soanes, D.M.; Talbot, N.J. CRISPR-Cas9 ribonucleoprotein-mediated co-editing and counterselection in the rice blast fungus. Sci. Rep. 2018, 8, 14355. [CrossRef]

123. Rosland, G.V.; Dyrstad, S.E.; Tusubira, D.; Helwa, R.; Tan, T.Z.; Lotsberg, M.L.; Pettersen, I.K.N.; Berg, A.; Kindt, C.; Hoel, F.; et al. Epithelial to mesenchymal transition (EMT) is associated with attenuation of succinate dehydrogenase (SDH) in breast cancer through reduced expression of SDHC. Cancer Metab. 2019, 7, 6. [CrossRef] [PubMed]

124. Munujos, P.; Collcanti, J.; Gonzalezsastre, F.; Gella, F.J. Assay of Succinate Dehydrogenase Activity by a Colorimetric-Continuous Method Using Iodonitrotetrazolium Chloride as Electron Acceptor. Anal. Biochem. 1993, 212, 506-509. [CrossRef]

125. Hollywood, K.A.; Shadi, I.T.; Goodacre, R. Monitoring the Succinate Dehydrogenase Activity Isolated from Mitochondria by Surface Enhanced Raman Scattering. J. Phys. Chem. C 2010, 114, 7308-7313. [CrossRef]

126. Old, S.L.; Johnson, M.A. Methods of microphotometric assay of succinate dehydrogenase and cytochromec oxidase activities for use on human skeletal muscle. Histochem. J. 1989, 21, 545-555. [CrossRef]

127. Škorjanc, D.; Heine, G.; Pette, D. Time-dependent increase of succinate dehydrogenase activity in low-frequency stimulated rabbit muscle: A comparison between microphotometric and biochemical methods. Histochem. Cell Biol. 1997, 107, 47-55. [CrossRef]

128. Huang, S.; Braun, H.-P.; Gawryluk, R.M.R.; Millar, A.H. Mitochondrial complex II of plants: Subunit composition, assembly, and function in respiration and signaling. Plant J. 2019, 98, 405-417. [CrossRef]

129. Schikowsky, C.; Senkler, J.; Braun, H.P. SDH6 and SDH7 Contribute to Anchoring Succinate Dehydrogenase to the Inner Mitochondrial Membrane in Arabidopsis thaliana. Plant Physiol. 2017, 173, 1094-1108. [CrossRef]

130. Panizza, E.; Ercolino, T.; Mori, L.; Rapizzi, E.; Castellano, M.; Opocher, G.; Ferrero, I.; Neumann, H.P.H.; Mannelli, M.; Goffrini, P. Yeast model for evaluating the pathogenic significance of SDHB, SDHC and SDHD mutations in PHEO-PGL syndrome. Hum. Mol. Genet. 2012, 22, 804-815. [CrossRef]

131. Park, S.J.; Chao, G.; Gunsalus, R.P. Aerobic regulation of the sucABCD genes of Escherichia coli, which encode alpha-ketoglutarate dehydrogenase and succinyl coenzyme A synthetase: Roles of ArcA, Fnr, and the upstream sdhCDAB promoter. J. Bacteriol. 1997, 179, 4138-4142. [CrossRef] [PubMed]

132. Leung, M.C.K.; Williams, P.L.; Benedetto, A.; Au, C.; Helmcke, K.J.; Aschner, M.; Meyer, J.N. Caenorhabditis elegans: An emerging model in biomedical and environmental toxicology. Toxicol. Sci. Off. J. Soc. Toxicol. 2008, 106, 5-28. [CrossRef]

133. Huang, J.; Lemire, B.D. Mutations in the C. elegans Succinate Dehydrogenase Iron-Sulfur Subunit Promote Superoxide Generation and Premature Aging. J. Mol. Biol. 2009, 387, 559-569. [CrossRef]

134. Piruat, J.I.; Millán-Uclés, A. Genetically modeled mice with mutations in mitochondrial metabolic enzymes for the study of cancer. Front. Oncol. 2014, 4, 200. [CrossRef]

135. Aspuria, P.-J.P.; Lunt, S.Y.; Väremo, L.; Vergnes, L.; Gozo, M.; Beach, J.A.; Salumbides, B.; Reue, K.; Wiedemeyer, W.R.; Nielsen, J.; et al. Succinate dehydrogenase inhibition leads to epithelial-mesenchymal transition and reprogrammed carbon metabolism. Cancer Metab. 2014, 2, 21. [CrossRef] [PubMed]

136. Ravegnini, G.; Ricci, R. Succinate Dehydrogenase-Deficient Gastrointestinal Stromal Tumors: Small Steps Toward Personalized Medicine? Epigenet Insights 2019, 12, 2516865719842534. [CrossRef]

137. Sarkadi, B.; Meszaros, K.; Krencz, I.; Canu, L.; Krokker, L.; Zakarias, S.; Barna, G.; Sebestyen, A.; Papay, J.; Hujber, Z.; et al. Glutaminases as a Novel Target for SDHB-Associated Pheochromocytomas/Paragangliomas. Cancers (Basel) 2020, 12, 599. [CrossRef]

138. Lussey-Lepoutre, C.; Hollinshead, K.E.; Ludwig, C.; Menara, M.; Morin, A.; Castro-Vega, L.J.; Parker, S.J.; Janin, M.; Martinelli, C.; Ottolenghi, C.; et al. Loss of succinate dehydrogenase activity results in dependency on pyruvate carboxylation for cellular anabolism. Nat. Commun. 2015, 6, 8784. [CrossRef]

139. Guo, L.; Zhang, H.; Chen, B. Nivolumab as Programmed Death-1 (PD-1) Inhibitor for Targeted Immunotherapy in Tumor. J. Cancer 2017, 8, 410-416. [CrossRef] [PubMed]

140. Toledo, R.; Jimenez, C. Recent advances in the management of malignant pheochromocytoma and paraganglioma: Focus on tyrosine kinase and hypoxia-inducible factor inhibitors. F1000Research 2018, 7. [CrossRef]

141. Milne, J.L.S.; Borgnia, M.J.; Bartesaghi, A.; Tran, E.E.H.; Earl, L.A.; Schauder, D.M.; Lengyel, J.; Pierson, J.; Patwardhan, A.; Subramaniam, S. Cryo-electron microscopy-a primer for the non-microscopist. FEBS J. 2013, 280, 28-45. [CrossRef] 
142. Nishikura, K. A-to-I editing of coding and non-coding RNAs by ADARs. Nat. Rev. Mol. Cell Biol. 2016, 17, 83-96. [CrossRef]

143. Thomou, T.; Mori, M.A.; Dreyfuss, J.M.; Konishi, M.; Sakaguchi, M.; Wolfrum, C.; Rao, T.N.; Winnay, J.N.; Garcia-Martin, R.; Grinspoon, S.K.; et al. Adipose-derived circulating miRNAs regulate gene expression in other tissues. Nature 2017, 542, 450-455. [CrossRef]

144. Bisbach, C.M.; Hass, D.T.; Robbings, B.M.; Rountree, A.M.; Sadilek, M.; Sweet, I.R.; Hurley, J.B. Succinate Can Shuttle Reducing Power from the Hypoxic Retina to the $\mathrm{O}_{2}$-Rich Pigment Epithelium. Cell Rep. 2020, 31, 107606. [CrossRef]

145. Brown, G.D.; Denning, D.W.; Gow, N.A.; Levitz, S.M.; Netea, M.G.; White, T.C. Hidden killers: Human fungal infections. Sci. Transl. Med. 2012, 4, 165rv113. [CrossRef]

146. Duvenage, L.; Munro, C.A.; Gourlay, C.W. The potential of respiration inhibition as a new approach to combat human fungal pathogens. Curr. Genet. 2019, 65, 1347-1353. [CrossRef] [PubMed]

147. Zhao, T.; Mu, X.; You, Q. Succinate: An initiator in tumorigenesis and progression. Oncotarget 2017, 8, 53819-53828. [CrossRef] [PubMed]

148. Wang, F.; Zuroske, T.; Watts, J.K. RNA therapeutics on the rise. Nat. Rev. Drug Discov. 2020, 19, 441-442. [CrossRef]

149. Nogrady, B. The challenge of delivering RNA-interference therapeutics to their target cells. Nature 2019, 574, S8-S9. [CrossRef]

150. Guo, P.; Haque, F.; Hallahan, B.; Reif, R.; Li, H. Uniqueness, advantages, challenges, solutions, and perspectives in therapeutics applying RNA nanotechnology. Nucleic Acid Ther. 2012, 22, 226-245. [CrossRef] [PubMed]

Publisher's Note: MDPI stays neutral with regard to jurisdictional claims in published maps and institutional affiliations. 